\title{
Evaluation of Aesthetic, Functional, and Environmental Effects on the Design of Urban Open Spaces: A Case Study of İstanbul Şişhane Park, Turkey
}

\author{
M.A. Samar Hamameh 1 (1), * Dr. Gökçen Firdevs Yücel Caymaz ${ }^{2}$
}

1 and 2 Department of Architecture, Faculty of Architecture and Design, Istanbul Aydın University, Istanbul, Turkey 'Email: samarhamameh@stu.aydin.edu.tr ,2Email: gokcenfyucel@aydin.edu.tr

\section{ART I CLE INFO:}

\section{Article history:}

Received 8 July 2019

Accepted 25 August 2019

Available online 8 September 2019

\section{Keywords:}

Urban Public Spaces;

Architectural Style;

Aesthetic;

Functional:

Environmental

Performance.

\begin{abstract}
A B S T R A C T
Urban spaces reflect the reality of city life, like a mirror. This research aims to examine and analyze the advanced aesthetic, functional, and environmental performance of urban public spaces by assessing the current situation and highlighting the role of creativity in developing these spaces. To clarify the research scope, Şishane Park in Istanbul, Turkey was studied to define the requirements of creative standards, evaluate these competencies and choose the appropriate architectural style and urban furniture. In addition, to learn ways of preserving those elements for longer life. The analytical descriptive approach was the research method utilized in order to arrive at a set of results that ascertain the reality of the aesthetic, functional, and environmental performance of urban public spaces, and the reflection of the contemporary role in developing these spaces, which can contribute to addressing weaknesses and bolster the strong points in the formation of public urban spaces around the world.
\end{abstract}

JOURNAL OF CONTEMPORARY URBAN AFFAIRS (2020), 4(2), 67-86.
Copyright (C) 2019 Journal of Contemporary Urban Affairs. All rights reserved.

\section{https://doi.org/10.25034/ijcua.2020.v4n2-7}

\section{www.ijcua.com}

\section{Introduction}

Urban spaces are considered one of the essentials of the city's urban structure because of their great importance to the community and human communication, to conduct many activities that can't be carried out within the residential area, and to achieve physical and psychological comfort in squares and parks to suit the community of diverse ages and socioeconomic levels (Al-Dweikat, 2009).
The lack of sufficient green recreation space has garnered the attention of urban planners to create new recreational spaces.

*Corresponding Author:

Department of Architecture, Faculty of Architecture and

Design, Istanbul Aydın University, Istanbul, Turkey

Email address: gokcenfyucel@aydin.edu.tr 
In addition, there is a clear deterioration in urban and visual perception such as lack of creating a distinctive urban design, lack of arrangement and equipment with appropriate fixtures, and visual and noise pollution spread due to traffic jams, neglecting climate factors and not satisfying them with sufficient vegetation and water elements, places filled with rubbish, covered with graffiti, filled with unsightly, poorly maintained buildings, unsafe by the homeless at night. Moreover, there is an emergence of psychological problems caused by social diseases due to poor interaction between human and landscape (the relationship between observer and landscape), the neglect of the important role of art in our modern world, and social diseases are caused by a lack of understanding of how urban spatial structure affect the psychological well-being of people who use urban space. The need for attention and clear intention to the urban environment has become greater and more important than ever because it is the most important place in our cities, where the greatest human communication and interaction occurs (Tibbalds, 1992).

1.1 Significance of this Research and Its Objectives

The significance of this study is to describe some of the most important problems and challenges plaguing urban open spaces around the world, and Turkey in particular. These include the wasting of visual and aesthetic elements enjoyed in urban spaces, the lack of attractive elements that meet the needs of the population, unavailability of comfort and social activities, lack of intentional design to serve and promote the obvious interaction between the community and nature, and the lack of a satisfying response to the social, psychological, and behavioural needs of the users of these urban spaces.

The aim of this research is to improve the aesthetic, functional, and environmental efficiency of urban open spaces by inspiring the possibility of addressing some aspects of the imbalance in space configuration. Upgrades to this configuration must match the importance of historical and touristic cities, thus this research seeks to demonstrate the role of urban open spaces in the aesthetic, functional, and environmental appearance of the city by presenting global examples that succeed in achieving the most important conditions required to reach the desired effect. Lastly, this study emphasizes the importance of the integration between the design process and urban planning, between science and art, to achieving functionality and meeting community needs.

\section{Methods and Materials}

Relying on the inductive analytical approach, the concept of integrated urban open space will be presented in this research. It highlights the most important standards and requirements to reach an efficient urban open space selected from published books and research by important authors in the urban design world. To make these practical, this paper analyses successful urban open spaces that meet the standards and requirements, while aptly demonstrating the integration of aesthetics, function, and the environment:

- $\quad$ "Sound Wave" in China, characterized by its unique aesthetic characteristics, a new design idea, the use of appropriate materials, attractive colour selection, and revitalization of the country's heritage through traditional Chinese music for visitors.

- "Superkilen" in Denmark notable for its success in meeting a variety of functional needs including containment of many recreational activities that can be performed, respect for all categories of people, embrace of many different nationalities in one urban open space, and the application of new taken ideas from the civilizations of different countries.

- "Victor Civita Plaza" in Brazil is based on an innovative approach to revitalizing a polluted urban area and preserving the environment, creating a new sustainable solution, and continuing this approach by providing visitors with greater environmental awareness.

Additionally, this paper analyses the demonstration of the standards by the case study of "Şışhane Park" in Istanbul, Turkey between the date of its establishment in 2014 and July 2019. Comprehensive assessment of these characteristics was conducted through visits to the site, review of changes to the urban space, and photos illustrating the current situation. The analysis of Şışhane Park asks:

- Have all the requirements of an efficient urban open space been met?

- $\quad$ Did the passage of time affect the quality and performance?

- What are the most affected elements?

\section{Literature Review}

- Urban spaces include a huge amount of activities and movement and large numbers of a city's population. The importance of urban spaces lies in their 
influence on the lives and behaviour of individuals in the urban environment, which serves multiple functions that are considered to be at the heart of the public's best interest. It can be a place of comfort and psychological balance for the urban population, stimulating social relations among the community, and instilling a sense of belonging and familiarity to their residential areas, while also providing aesthetic touches to the urban environment (Figure 1).

- Through the intentional design of urban open spaces, they can preserve the environment in thoughtful ways, for example by use of certain materials that are harmless to the environment. Its usefulness is

- also greater and more comprehensive if it meets all the aesthetic, functional, and environmental required terms and is designed with creative ideas, keeps pace with modernity and technology to reach the highest level to achieve its goal.

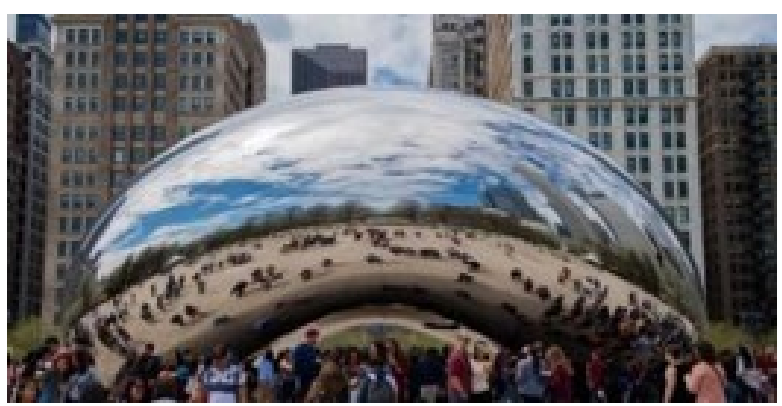

Figure 1. Anish Kapoor's Cloud Gate, in Chicago's Millennium Park, 2004 [URL1; URL2]

The city is described as an element representing the social and spiritual culture of society. Urban spaces in any urban configuration can be considered as the remaining non-built areas of the city, whether planned or unplanned, and these spaces include roads, public squares, green areas, and playgrounds (Krier, 1991). Urban spaces can focus representation of important parts of the city's culture and show the relationships and ratios among its different parts (Figure 2). They even can form the city, serving as population assembly points and cross-sections of movement, and the city supports these spaces through the good organization of its surroundings and good guidance for the paths leading to them (Lynch, 1960). Regardless of the diverse uses of urban spaces, these urban spaces are places where the physical elements are defined by the human activities conducted in them, each having a key role to influence how they are used.

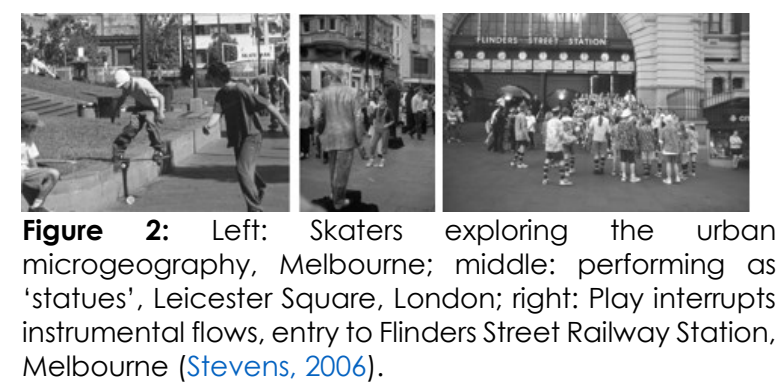

The researchers Kevin Lynch (1960), Jane Jacobs (1961), Allen Jacobs \& Appleyard (1987), Francis Tibbalds (1992), Rob Krier (1979), and Carmona \& others (2010) were interested in one of the urban space characteristics - aesthetics, function, or the environment. They elaborated on only one aspect, without explaining the relationship between the characteristics of urban space and their impact on each other (Table 1).

Table 1: Classification of aesthetic, functional, and environmental criteria for urban space from the perspective of several researchers.

\begin{tabular}{|c|c|c|c|c|c|}
\hline Aesthetic Aspect of Urban Space & Source & $\begin{array}{l}\text { Functional Aspect of Urban } \\
\text { Space }\end{array}$ & Source & $\begin{array}{l}\text { Environmental Aspect of } \\
\text { Urban Space }\end{array}$ & Source \\
\hline $\begin{array}{l}\text { Compatibility and harmony } \\
\text { between urban elements } \\
\text { Proportionality } \\
\text { Ability to sense and communicate } \\
\text { Understanding the place } \\
\text { Vitality, similarity, color, shape, } \\
\text { transparency, simplicity } \\
\text { Organization of the movement }\end{array}$ & $\begin{array}{c}\text { Kevin Lynch, } \\
1960\end{array}$ & $\begin{array}{l}\text { Method of organizing public } \\
\text { spaces. } \\
\text { Nature of activities. } \\
\text { Outdoor open space. } \\
\text { Entertainment. } \\
\text { Sports events. } \\
\text { Vehicles' and pedestrian's } \\
\text { movement. } \\
\text { Urban hygiene and reduction of } \\
\text { pollution in all its forms. }\end{array}$ & $\begin{array}{c}\text { Rob Krier, } \\
1979\end{array}$ & $\begin{array}{l}\text { Climate } \\
\text { Geology and Earth Form } \\
\text { Water and discharge } \\
\text { Topography } \\
\text { Vegetation and ecological } \\
\text { nature } \\
\text { Natural visual features } \\
\text { Social welfare } \\
\text { Environmental awareness }\end{array}$ & $\begin{array}{c}\text { Turner, } \\
1980\end{array}$ \\
\hline $\begin{array}{l}\text { Vitality } \\
\text { Flexible spaces availability } \\
\text { Linking users socially } \\
\text { To be able to carry out various } \\
\text { activities }\end{array}$ & $\begin{array}{l}\text { Jane Jacobs, } \\
1961\end{array}$ & $\begin{array}{l}\text { The multiplicity of uses the urban } \\
\text { space. } \\
\text { The multiplicity of activities that } \\
\text { can be carried out within this } \\
\text { space. } \\
\text { Accessibility for all people. }\end{array}$ & $\begin{array}{c}\text { Francis } \\
\text { Tibbalds, } \\
1992\end{array}$ & $\begin{array}{l}\text { Ethics and respect for } \\
\text { individual } \\
\text { Participation and } \\
\text { democratization } \\
\text { Structuring through } \\
\text { networks }\end{array}$ & $\begin{array}{c}\text { Ekhart } \\
\text { Hahn, } \\
1987\end{array}$ \\
\hline
\end{tabular}




\begin{tabular}{|c|c|c|c|c|c|}
\hline & & $\begin{array}{l}\text { Creating clear and permanent } \\
\text { environments. } \\
\text { Encouraging and organizing the } \\
\text { pedestrian movement. }\end{array}$ & & $\begin{array}{l}\text { The natural world and } \\
\text { sensory experience } \\
\text { Urban density } \\
\text { Respect for a spirit of place } \\
\text { Ecology and economy }\end{array}$ & \\
\hline $\begin{array}{l}\text { Visual perception } \\
\text { Achieving joy and social } \\
\text { communication } \\
\text { Maintain the identity of the place } \\
\text { Originality }\end{array}$ & $\begin{array}{l}\text { Allen Jacobs } \\
\text { \& Appleyard, } \\
1987\end{array}$ & \multirow{4}{*}{$\begin{array}{l}\text { General criteria } \\
\text { Taking into account site topography. } \\
\text { Nature of soil and climate. } \\
\text { Provide an adequate share of the } \\
\text { individual's activities and services. } \\
\text { Achieving communication between } \\
\text { the elements of the urban space and } \\
\text { the surrounding environment. } \\
\text { Maintain it as a continuous natural } \\
\text { resource. } \\
\text { Protect it from noise and pollution. } \\
\text { Spiritual criteria } \\
\text { Comforts. } \\
\text { Diversity. } \\
\text { Visual perception. } \\
\text { Excellence and unique personality. } \\
\text { Support positive behavior. } \\
\text { Users the cultural and social } \\
\text { characteristics } \\
\text { Special criteria } \\
\text { By type of activity. } \\
\text { Achieving privacy. } \\
\text { Appropriate guidance. } \\
\text { Security. } \\
\text { Movement organization. }\end{array}$} & \multirow[t]{4}{*}{$\begin{array}{c}\text { Kevin Lynch, } \\
1994\end{array}$} & \multirow{4}{*}{$\begin{array}{l}\text { Achieve multiple urban } \\
\text { spaces } \\
\text { Social interaction } \\
\text { Giving vitality to the } \\
\text { neighborhood unity } \\
\text { Link and sense of place } \\
\text { Integration of land uses, } \\
\text { which promotes social, } \\
\text { economic and } \\
\text { environmental returns } \\
\text { Focus on mass transport } \\
\text { (public) taking into } \\
\text { consideration (private } \\
\text { transport) } \\
\text { Integrations between } \\
\text { traditional principles with } \\
\text { contemporary needs } \\
\text { Achieving sustainability } \\
\text { goals }\end{array}$} & \multirow[t]{4}{*}{$\begin{array}{l}\text { Williams } \\
\text { \& others, } \\
2000\end{array}$} \\
\hline $\begin{array}{l}\text { Influence on the old architectural } \\
\text { thought } \\
\text { The link between past and present } \\
\text { Human scale and Proportionality } \\
\text { Clarity } \\
\text { Texture }\end{array}$ & $\begin{array}{c}\text { Francis } \\
\text { Tibbalds, } \\
1992\end{array}$ & & & & \\
\hline $\begin{array}{l}\text { Urban image quality } \\
\text { Influence on the old architectural } \\
\text { thought } \\
\text { Clarity } \\
\text { Imagination }\end{array}$ & $\begin{array}{c}\text { Punter \& } \\
\text { Carmona, } \\
1997\end{array}$ & & & & \\
\hline $\begin{array}{l}\text { Visibility of cultural identity } \\
\text { The urban space should be natural } \\
\text { Shape, lines, color, materials }\end{array}$ & Nasar, 1998 & & & & \\
\hline $\begin{array}{l}\text { Simplicity } \\
\text { Harmony } \\
\text { Clarity of visual perception } \\
\text { Excellence } \\
\text { Comforts } \\
\text { Security }\end{array}$ & $\begin{array}{l}\text { Borton \& } \\
\text { Mitchell, } \\
2006\end{array}$ & \multirow{2}{*}{$\begin{array}{l}\text { Movement and activity. } \\
\text { Organizing the movement of } \\
\text { vehicles and pedestrians. } \\
\text { Communication and optical } \\
\text { permeability. } \\
\text { Activities in public space. } \\
\text { Social communication. } \\
\text { Privacy. } \\
\text { Population density. } \\
\text { Environmental design. } \\
\text { Open public space. } \\
\text { Design for walking. } \\
\text { Benefit from the infrastructure of } \\
\text { the place. }\end{array}$} & \multirow[t]{2}{*}{$\begin{array}{c}\text { Carmona \& } \\
\text { others, } 2010\end{array}$} & \multirow{2}{*}{$\begin{array}{l}\text { Direct the spaces according } \\
\text { to sunlight and shade } \\
\text { The sunshine penetrate the } \\
\text { urban spaces which makes } \\
\text { it more enjoyable places } \\
\text { Mobilize and assemble } \\
\text { buildings } \\
\text { Fountains to enhance } \\
\text { natural cooling } \\
\text { Environmental pollution } \\
\text { Air and wind movement } \\
\text { Supply of potable water } \\
\text { Good drainage of } \\
\text { wastewater } \\
\text { Trash disposal }\end{array}$} & \multirow[t]{2}{*}{$\begin{array}{l}\text { Carmona } \\
\text { \& others, } \\
2010\end{array}$} \\
\hline $\begin{array}{l}\text { Ratio and proportionality. } \\
\text { The human scale. } \\
\text { Movement. } \\
\text { Lines and shapes. } \\
\text { Colors, Texture, Items, Materials. }\end{array}$ & $\begin{array}{c}\text { Hani Al } \\
\text { Farran, } 2010\end{array}$ & & & & \\
\hline
\end{tabular}

\subsection{Aesthetic Classification Criteria for Urban Open Space}

Aesthetics is the study of sensations, concepts, and judgments of people, derived from our understanding of art (Blackburn, 1994). It is essential to clarify there is a disparity between beauty and aesthetics. The term "beauty" is the peculiar attribute of an object, place, or element that the human senses experience as pleasure, satisfaction, and acceptance; but the term "aesthetics" refers to the philosophical side of beauty and its appreciation (Nia and Atun, 2015). The aesthetic concept refers to the importance of recognizing beautiful elements and images at several levels such as visual and auditory, as well as spiritual cognition, to reach the reality of any phenomenon that affects emotions. Aesthetics are also the sensory value that an individual feel about the contours of things, through which the individual is pleased, and with such pleasure and enjoyment that the individual self has felt of the value of his/her existence. Architecture, sculptural art, music, and other things that the individual, and society in general, enjoy are products created by creative thought, so the outcome is a concrete form to be dealt with, to please an innate need of humans (Abdullah, 2009). The relationship between the location and how to understand the population needs is an important factor for enhancing the urban life quality, which is why aesthetics science has a key role in the development of space through the understanding of psychological sentiment (Alyari, 2018). To create a delightful urban space, many features are proposed, such as vibrancy, richness, multi-use environment, interactive, and full of people at night and on weekends, visually 
motivating, and attractive for residents and visitors (Figure 3) (Shaftoe, 2008).

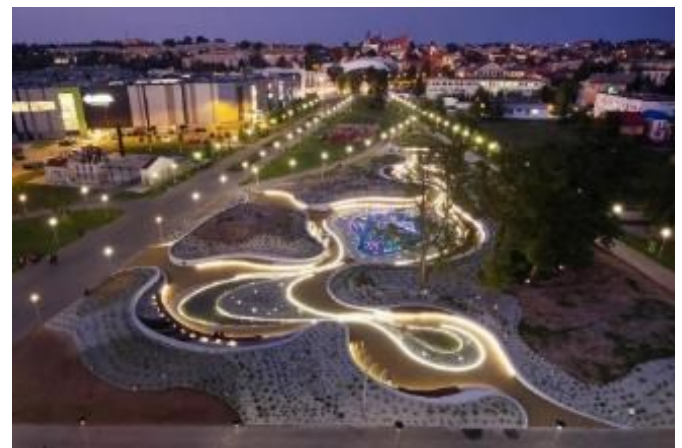

Figure 3: Jaworznickie Planty Water Playground, Jaworzno, Poland [URL3]

By studying the opinions of the authors whose names were mentioned in Table 1, the essential aesthetic characteristics were chosen for their importance, and analysis was conducted on the best example of the required criteria for aesthetics in "Sound Wave" in China, and the use of the designer's approach to this distinctive urban open space, as shown in Table 2. There are ten essential aesthetic elements to consider when designing and analyzing an open urban space: harmony of design elements, ratios and measures, texture, color, materials, lighting, visual perception, audiovisual perception, urban space coordination, and psychological effect.

As the lack of interdependence of the elements of urban open space negatively affects the aesthetics clearly, the user will inevitably feel this imbalance, so the harmony of design elements is crucial for design. The aspect of ratios and measures were chosen because the human scale should be regarded when designing an urban open space, to be usable for all ages, and to make the user feel comfortable and belonging to the place.

The aesthetics of urban open space also deals with texture, color, and materials. The texture has a clear effect on the perception of the space. Nature is characterized by a blend of colors, so choosing the appropriate colors, suitable for the place, and the way they blend with each other in the urban open space attracts users and make a good impression. Successful selection of specific materials when making any urban open space has a role in highlighting its identity, the beauty of ugliness of the place.

Aesthetics are affected by lighting, visual, and audiovisual perceptions. For the lighting factor, sun lighting and natural lighting adopt an important role in the formation of urban open space, as well as the distribution of artificial lighting and optical dots at night. These have a prominent role in the completion of its overall aesthetic image. As well, the visual and audiovisual perception factor of urban open space and the surrounding area has a role in raising its efficiency, so they must be studied and considered carefully in design.

For the element of urban space coordination, all elements should be linked together smoothly and dynamically to facilitate the movement of visitors, and generate feelings of joy and the desire to discover the place. After incorporating all the above elements, the question arises about the generated psychological effect within the users - feelings of belonging or discomfort, positive or negative impression, and the desire to return to the same urban open space again or not.

\subsubsection{Analysis of the Aesthetic Elements in the Study Area; Sound Wave in China}

Table 2: Selection of the most prominent Aesthetic elements in "Sound wave" (analyzed by the authors) (Figures source: URL4)

Aesthetic Elements

(Defined and selected by authors)

The Harmony of design elements

The "Soundwave" represents the entrance to a large garden. The music, rhythm, and dance with the surrounding landscape were the main landmarks that makeup it.

\section{Ratios and measures}

These fins kept the human scale according to their various heights, this urban space can be used by all age groups.

\section{Texture}

These fins suggest lightness, agility, and harmony in addition to their beautiful shape.

\section{"Sound Wave" In China}
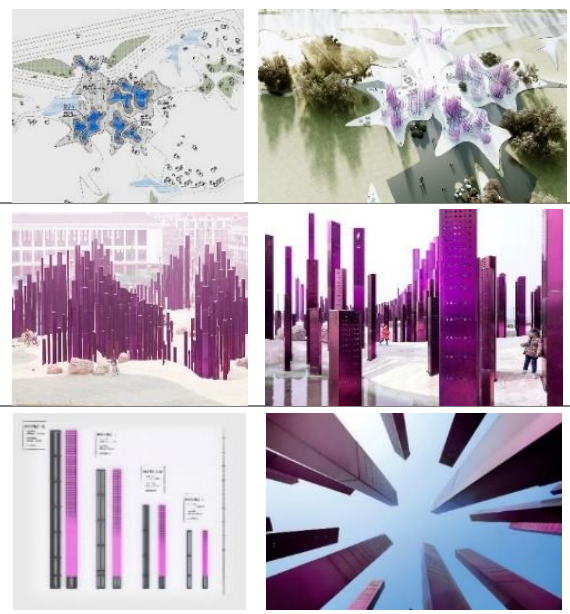


\title{
Color
}

The fins have vibrant colors, holds four degrees from the purple color.
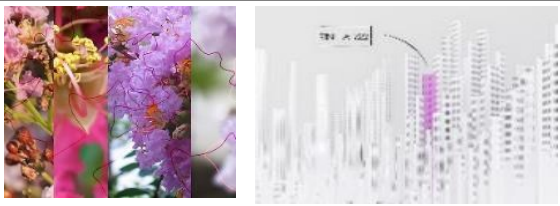

\section{Materials}

The fins that make up the rhythm of the statue are covered with stainless perforated purple plates, through the process of electrocoagulation (oxidized), the panels are painted so that they maintain their main characteristics without defect and to resist corrosion. Light brightness and music volume are controlled by motion sensors around the site and are activated by pedestrian movement.

\section{Lighting}

The fins are located in four ponds of water, so the lamps are shining through the small holes in the steel at night, lighting the entrance and reflecting on the existing ponds of water to create a magnificent spectacle.
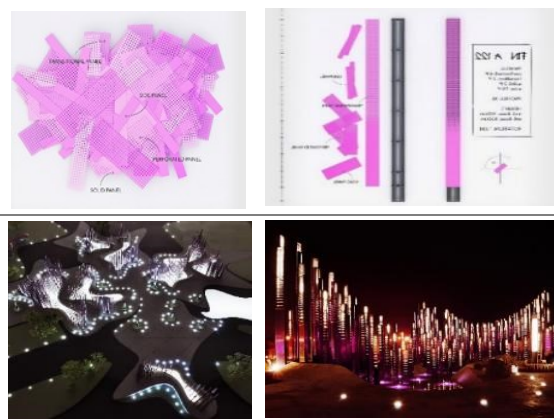

\section{Visual perception}

The statue consists of more than 500 perforated steel fins with vitality colors and varying in height, and the statue creates a visual milestone for the region.

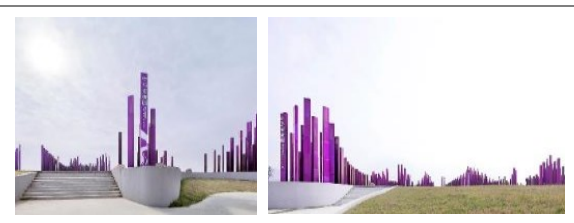

\begin{abstract}
Audiovisual perception
When visitors enter the Myrtle Tree Garden, they are surrounded by a lot of fins that spread like trees in the landscape, so that the speakers installed in some columns will play traditional Chinese music.
\end{abstract}

\section{Elements of urban space coordination}

This square is used during the evening by the local people for group dancing, the fins contain lines of lamps to produce the orchestra of 500 fins lighting connected to the square sound system and react in a direct and fast way with the movement in the square.
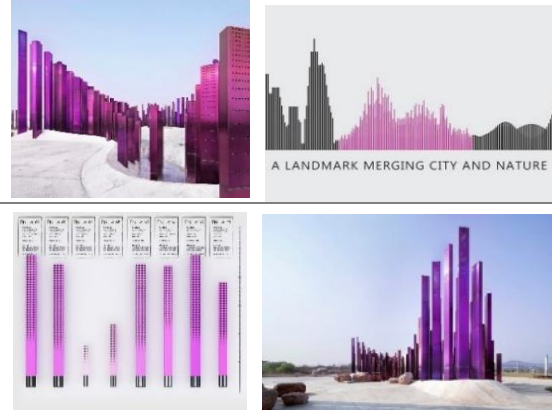

\section{Psychological impact}

When entering the square, the color and light will attract visitors in a sensual way to the landscape of Myrtle Tree Garden, to give visitors and local dance groups an opportunity to revive Soundwave during the day and night.

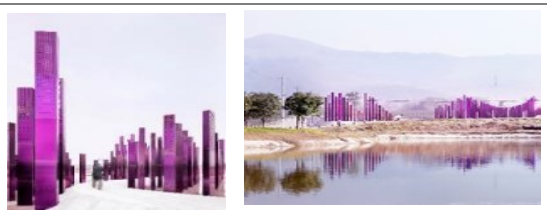

\subsection{Functional Classification Criteria for Urban Open Space}

The integration between the aesthetic and function in the urban space is one of the most important conditions of successful design seeking to create the civilized development of any city. The efficiency of designing and coordinating urban spaces depends on a set of functional criteria that any urban space should acquire to be able to perform its function at the highest degree of efficiency.

The functional urban space can be defined as the space in which it is possible to practice diverse activities according to the quality of the space and meeting the human needs from the space. These spaces are characterized by dynamism and movement, in which all forms of human activity interact with and through them. Functional urban spaces are formed as a result of the distribution of a set of buildings in a specific urban area, and its nonrandom spaces without a target, but it is a functional necessity that integrates with the multiple uses of residential areas (Elmashad, 2011).

The Superkilen in Denmark was analyzed through the essential elements of functional space in Table 3. The essential elements for function were selected for their association with the capacity of urban open space to achieve its function efficiently, and include the method of organizing the public space, diversity, special character, traffic movement, sports activities, communication and visual clarity, entertainment, comforts, and support of positive behaviour. The way in which urban space is organized and the choice of a diverse style in the design of its elements to include sports activities and entertainment, clearly affect its function. Space should also be characterized by a unique character that distinguishes it from other public places. Preferably traffic within and through space is considered in the design to be easy for all users. Lastly, space should create a sense of comfort for 
users and raises their morale to do positive

behaviours.

\subsection{Analysis of Functional Elements in the Study Area; Superkilen in Denmark}

Table 3: Selection of the most prominent Functional elements in "Superkilen" (analyzed by the authors) (Figures source: URL5) Functional Elements (Defined and selected by authors)

\section{The method of organizing the public space}

"Superkilen" is an urban open space in Nørrebro located in the Quarter of Mimersgade in one of the most ethnically diverse and socially cohabited neighbourhoods in Denmark. It can be considered as a diverse exhibition of best urban practices, which come from 60 different nationalities of people living in residential areas around it.

\section{Diversity}

"Superkilen" is a park that promotes diversity, it will be like a world exhibition filled with interesting things from around the world; including benches, lampposts, garbage cans, plants, and water fountains, as well as a variety of activities that can be done.

\section{Special Character}

The main idea of Superkilen's design is to the park is divided into three main areas: The Red Square, The Black Market, and The Green Park. While Red Square designates the modern, urban life with café, music, and sports. The Black Market is the classic square with fountain and benches. The Green Park is a park for picnics, sports and walking the dog.

\section{Traffic movement}

The traffic regulation in the park has been taken into account, the current cycling paths will be reorganized, and new links will be established linking the surrounding neighborhoods, including full traffic development in the Norrebro area.

\section{Sports activities}

There is a kind of integration among the local population through meetings and participation in physical activities, and entertainment shows held in the central square.

\section{Communication and visual clarity}

There is a high open space next to the large facade towards Norrebrogade, which enables visitors to enjoy stunning views, In addition to the cultural and sports facilities.

\section{Entertainment}

The square is covered with a multifunctional rubber surface to enable ball games, markets, parades, skating rinks in winter, and other activities. Portable platforms in Norrebrohallen can be moved there for open-air movie/outdoor sports performances. To the north, visitors will enjoy basketball courts, parking spaces, and an outdoor fitness area.

\section{Comforts}

This park has included inspired furniture by different cultures; to attract different segments of the population; Such as the Moroccan fountain, Iranian Cuban and Swiss benches, Japanese cherry trees, Norway maple, Thai boxing bags, Indonesian swings, British litter bins, bollards painted with the Ghanaian flag and Irish manhole covers. On weekdays, tables, and permanent barbecue facilities serve as an urban living room for the table game and chess players.

\section{Support positive behavior}

There is a playground where families with children can meet for picnics, sunbathing on the grass, as well as for hockey, badminton, and exercise. Many of the park's components were suggested by the residents themselves. In brief, Superkilen park might inspire many other cities as an example of how to approach the cultural diversity of their neighborhoods.

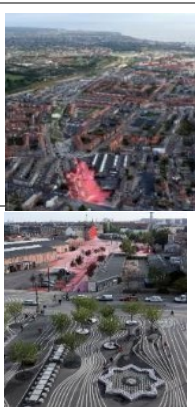

"Superkilen" in Denmark
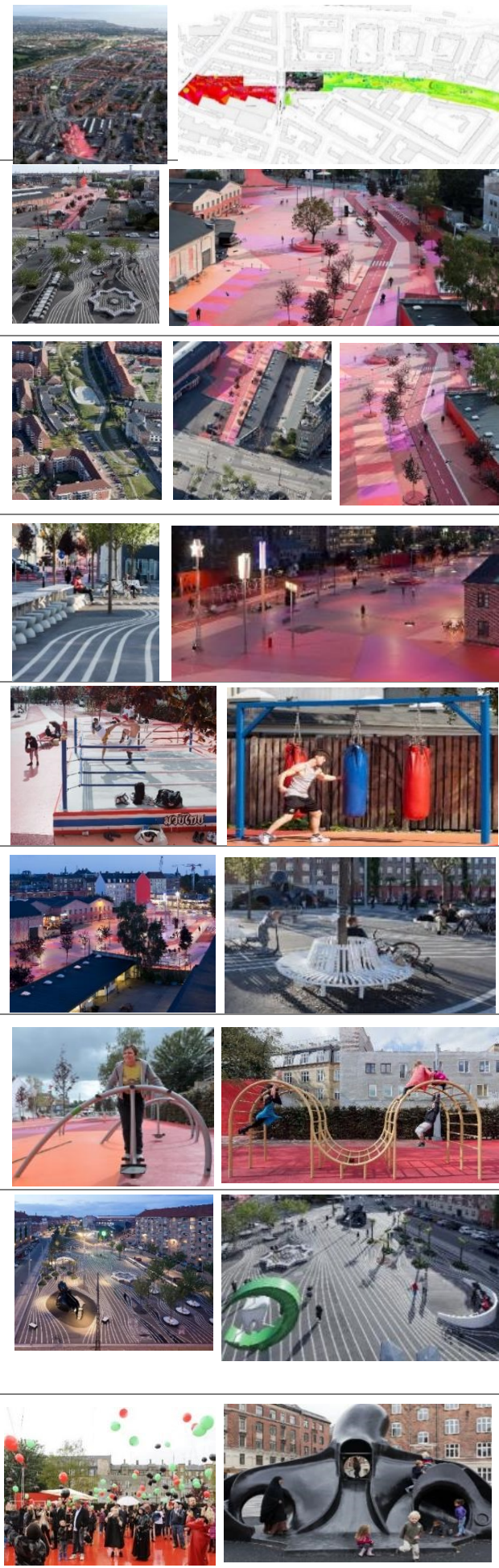


\subsection{Environmental Classification Criteria for Urban Open Space}

Urban planners currently face the challenge to revitalize neglected urban neighborhoods in ways that raise the level of health and promote equality (Corbum, 2009). They have the most important role in promoting a healthy environment to not only improve the quality of life of people living now, but also to plan for the health of future generations through the design of the environment in urban spaces (Barton \& Tsourou 2000). Natural factors such as sunlight, shade, temperature, humidity, wind, noise, pollution, and weather conditions affect the utilization of urban environments (Carmona \& others, 2010). As for global sustainable development, multi-disciplinary environmental ideas are applied to start with urban planning and land use, aiming to improve living conditions of the urban population through achieving a balance between technological progress and improving the health conditions of urban spaces (Gauzin-Müller and Favet, 2002). Taking into account environmental, social, and economic dimensions, the application of environmental standards in urban spaces improves the quality of urban space and raises the environmental reality through the transfer of best practices in the environmental architecture field and urban planning to achieve sustainable development of cities. It achieves important objectives such as: reducing the impact of urban development and technology on the natural system, preserving natural resources and discovering renewable energies, and attention to environmental areas that contain unique natural elements (Turner, 1980).
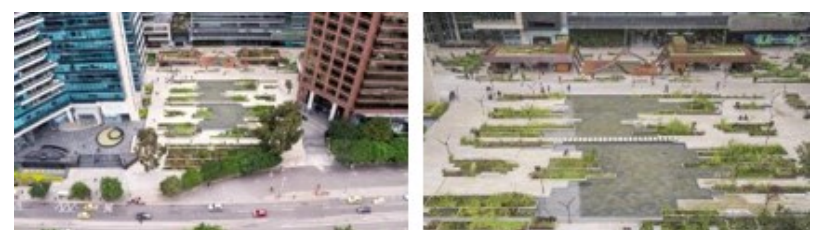

Figure 4: Usaquén Urban Wetland, Bogota, Colombia [URL6]

There are five essential elements to consider in urban space planning and design related to the environment: providing sustainable solutions, use of natural lighting and good ventilation, pollution treatment, return to nature and the sensory experience and raising the environmental awareness of the users. It was found to obtain a healthy urban open space and to preserve the environment, urban planners should consider sustainable solutions to the current environmental issues of the location. Spaces should consider relying on sun lighting and natural ventilation for creating comfortable spaces over the use of energy-consuming solutions to reduce the carbon footprint. Urban open spaces should seek to decrease environmental pollution through the activities of users. Further, it should be a space that gives people the desire to return to nature through positive sensory experiences. Lastly, space should promote the development of environmental awareness and a sense of responsibility to space and the overall environment (Figure 4).

\subsubsection{Analysis of the Environmental Elements in the Study Area; Victor Civita Plaza in Brazil}

Table 4: Selection of the most prominent environmental elements in "Victor Civita Plaza" (Analyzed by the authors) (Figures source: URL7)
Environmental Elements
"Victor Civita Plaza" In Sao Paulo, Brazil

(Defined by Authors)

\section{Provide a sustainable solution}

Located in a central urban area, the site of the garbage dump is also an innovative idea to revitalize a polluted urban area. A large wooden surface on the site was constructed without excavations.

\section{Natural lighting and good ventilation}

Natural lighting is relied upon and take advantage of sunlight for a more energetic feeling, and choosing the right direction to take advantage of the wind appropriately
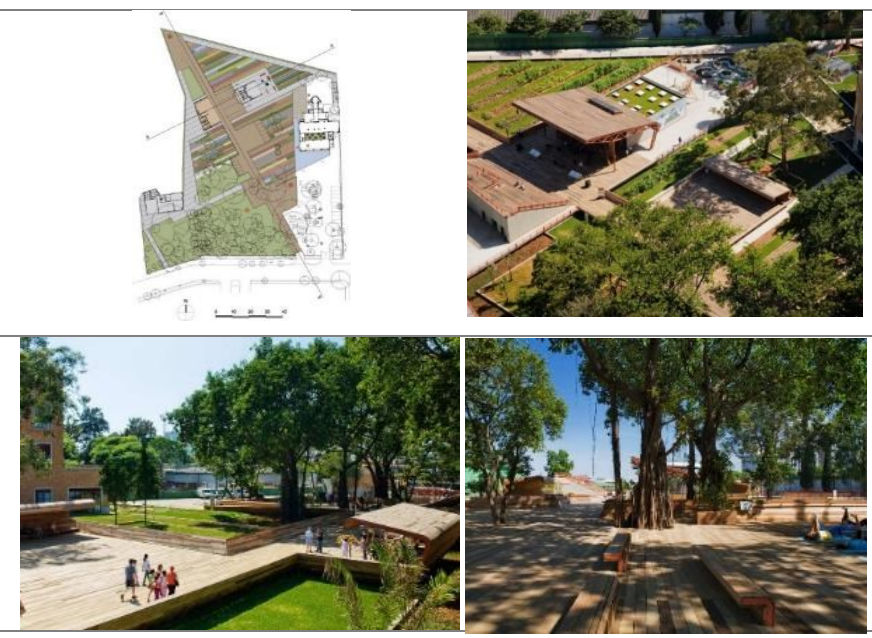


\section{Pollution treatment}

A new design has been proposed that addresses the problem of pollution through the application of a sustainable solution that integrates social, political, cultural and environmental elements.

\section{Return to nature and sensory experience}

Approved and recycled Brazilian hardwoods were selected over the site, supported by a steel structure, to reduce contact with contaminated soil, such as the frame of a ship.

The surface floats at a height of three feet above the original terrain and extends in a long diagonal shape. Exhibit panels explain the various sustainable processes in the plaza, including the recycling of wood.
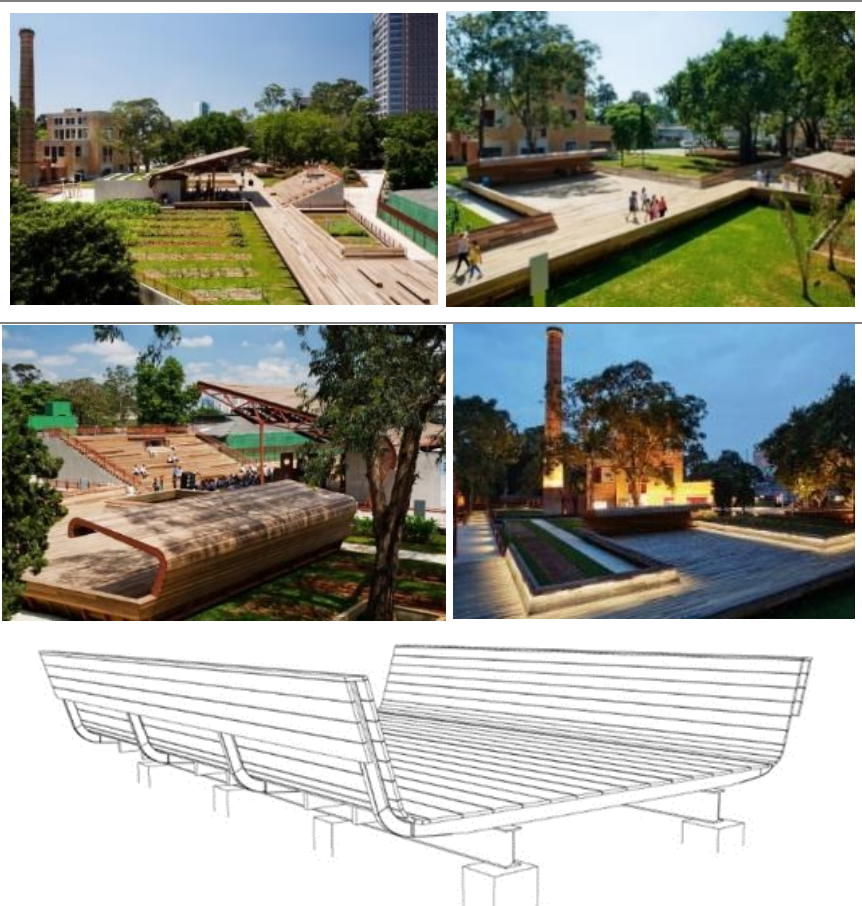

\section{Environmental awareness by users}

This environmental project aims to promote community participation and development. Visitors will be able to learn about the organic water recycling system used in the plaza; in pursuit of increasing their environmental awareness.
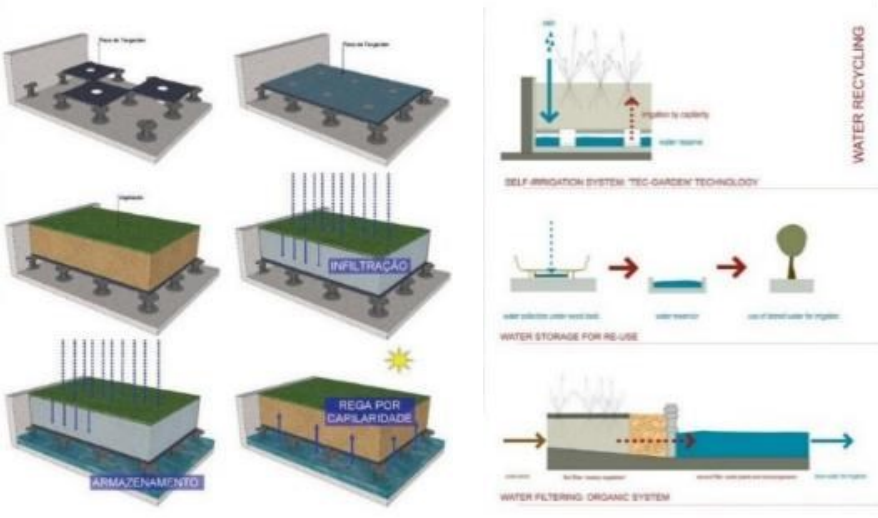

4. Case Study: "SIŞhane Park" in Istanbul, Turkey

\begin{tabular}{|l|l|}
\hline Architects & SANALarc \\
\hline Location & $\begin{array}{l}\text { Bereketzade Mh., Büyük Hendek } \\
\text { Caddesi No:50, } \\
\text { Beyoğlu/lstanbul, Turkey }\end{array}$ \\
\hline GPS Coordinates & $41^{\circ} 1^{\prime} 41.3364^{\prime \prime}$ and 28 58' 22.3248" \\
\hline Design Team & $\begin{array}{l}\text { Orkun Beydagi - Cibeles Sanchez } \\
\text { Llupart - Leo Pollor - Begüm Öner }\end{array}$ \\
\hline Area & $30000.0 \mathrm{~m} 2$ \\
\hline Project Year & 2014 \\
\hline Budget & $\$ 10 \mathrm{M}-50 \mathrm{M}$ \\
\hline
\end{tabular}

"Şişhane Park" is located adjacent to the historical area of Galata Suriçi in the European part of Istanbul between the southwest corner of Beyoğlu and Tarlabaşı streets. The aims of the park are: to reduce the entry of cars into the historic area and to reroute traffic density to enable users to experiment with alternative public spaces. Şişhane Park cuts through the city's streets with alternative approaches and unconventional elements compared to other parks in Istanbul. It aims to have distinctive lines in a location with historical importance, be attractive for quality social life and make people interact with natural materials like wood rails and others. The design is elliptical so the users don't lose visual and cognitive comfort. It is an open public space that has been formed as a park connected by vertical turnover lines connected by ramps and stairs. The park contains a playground, seating areas, walking trails, and six floors for parking where each floor is characterized by a different colour, so the user has different spatial experiences (Tay and Canbay Türkyilmaz, 2018).

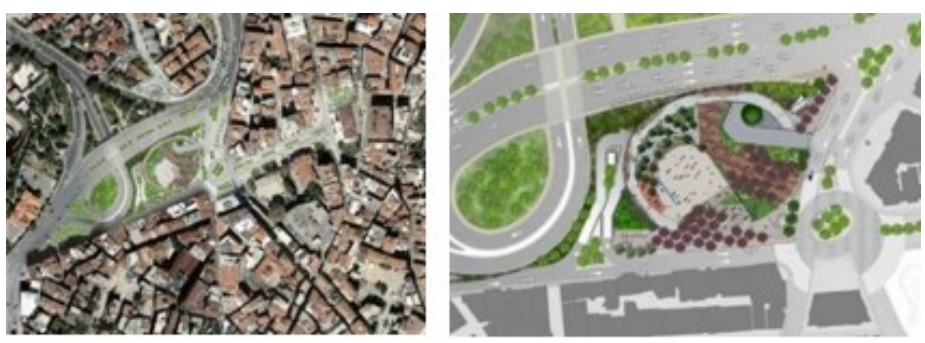

Figure 5: "Şıshane Park" Site Plan [URL8] 
Table 5. Highlight the strengths and weaknesses of "Şışhane Park"; (Improved by author; Figures source: by authors).

\section{Strengths of Şışhane Park}

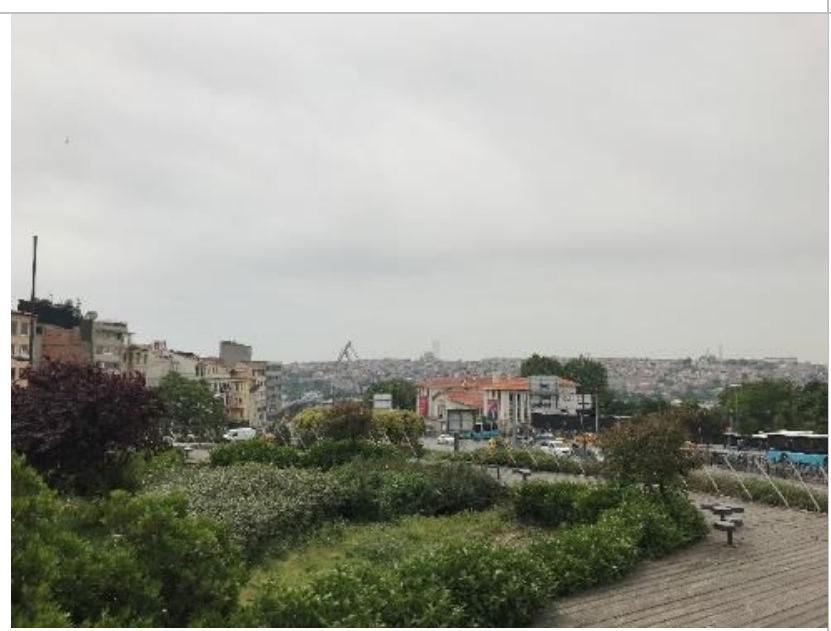

The location of the park gave it great importance and a beautiful view of Istanbul city.

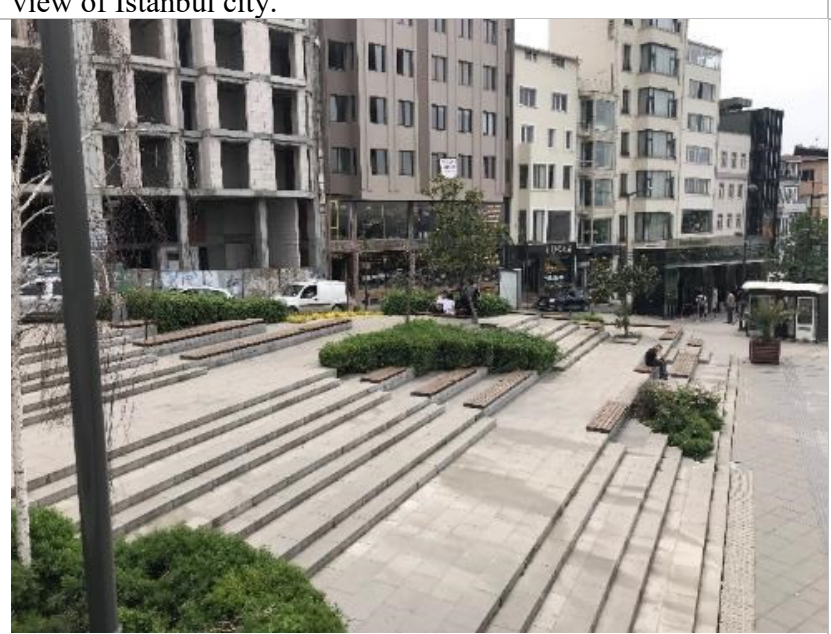

The gradient method of heights is good for the best view.

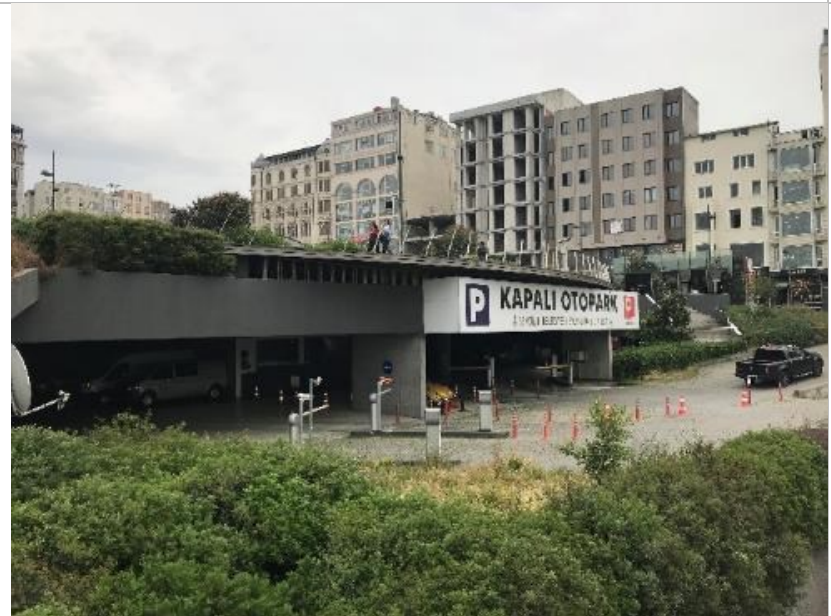

The presence of closed garage.

\section{Weaknesses of Şışhane Park}

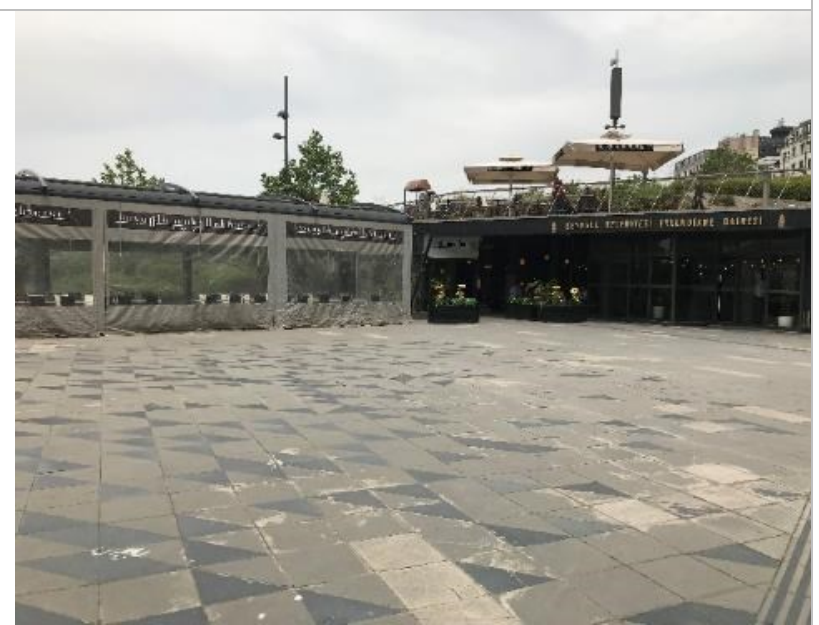

Having an outdoor café within the main square of the park is thoughtless and reduced the importance of the main square.

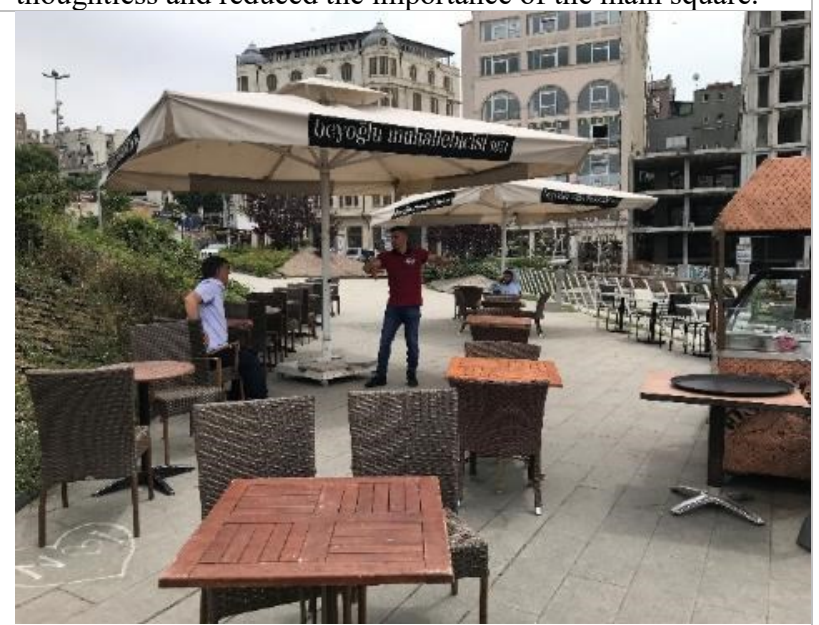

Putting the chairs and tables of the outdoor cafe in the middle of the main road for the park.

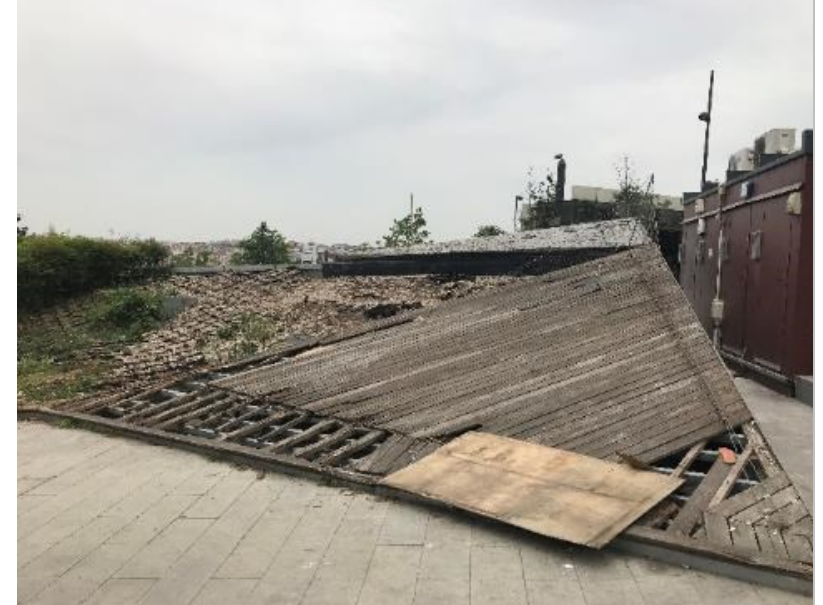

The elements of the Şışhane park are vulnerable to different weather conditions. 


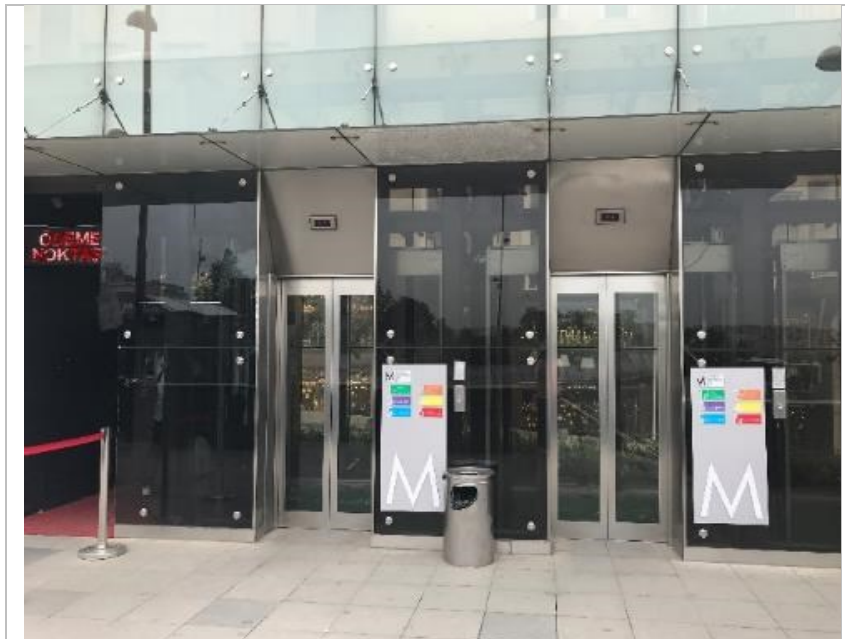

There are many elevators that link the closed garage's floors clearly.

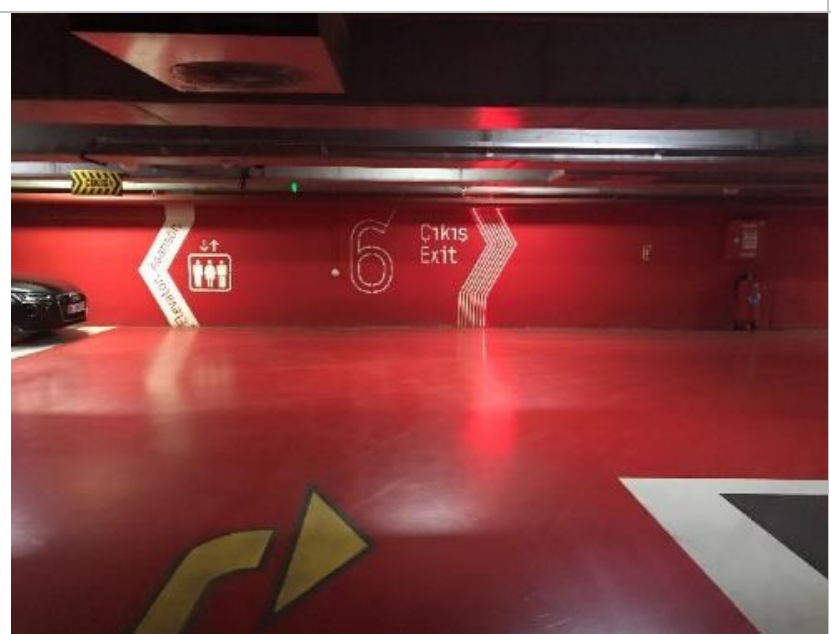

Each floor in the garage has a distinctive colour.

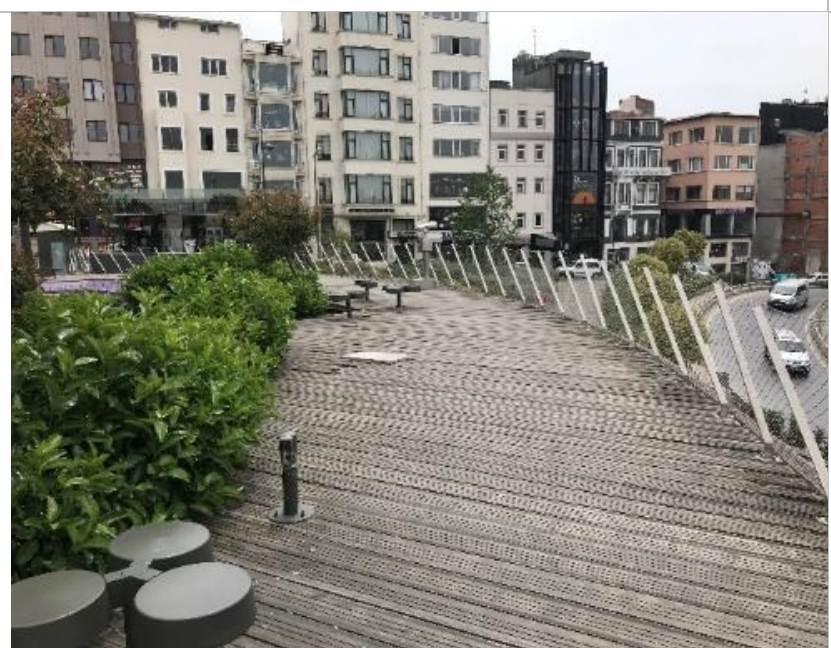

Garden paths link with each other well.

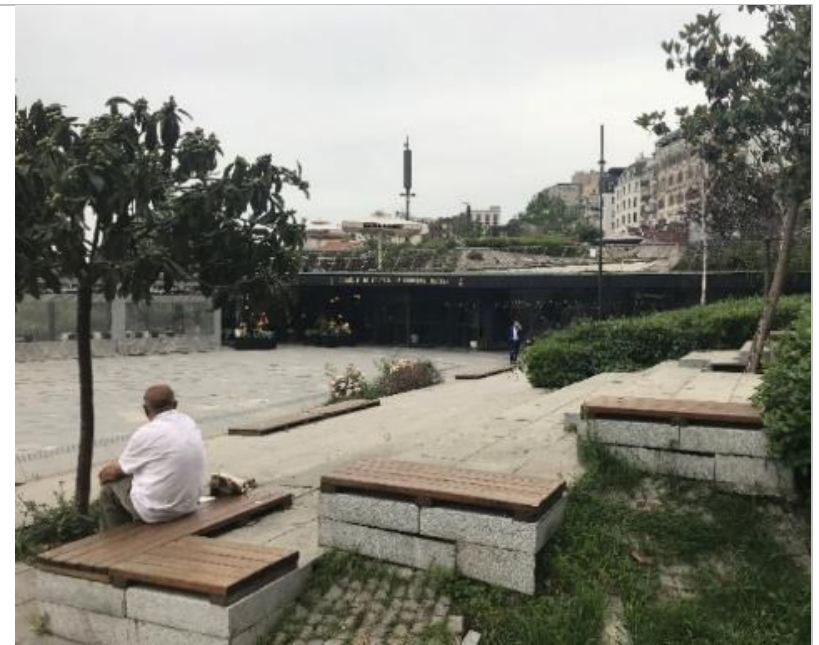

There is no urban furniture that protects users from sun, rain or any sudden weather fluctuations, reducing usability throughout the year.

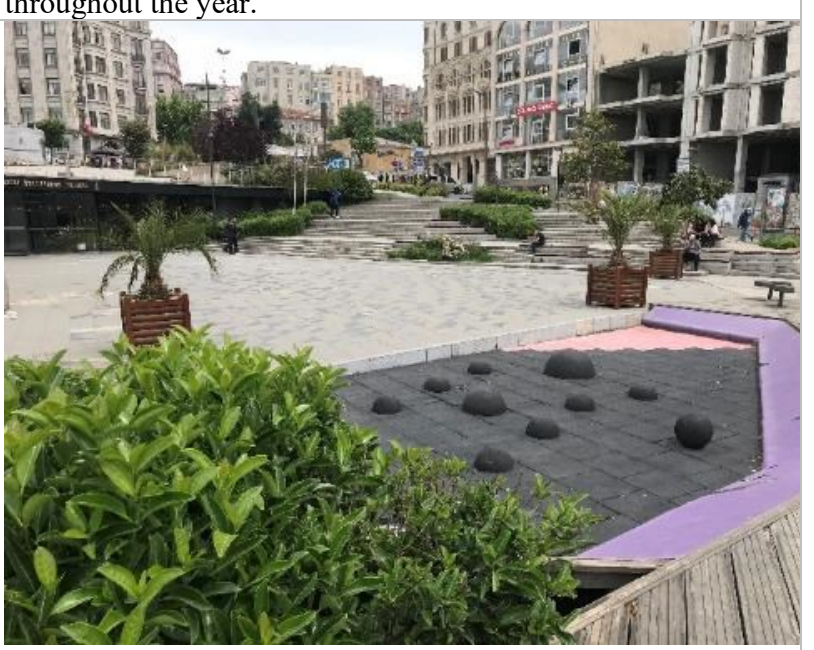

The entertainment corner in the Şışhane park is unusable because of damage to the used materials.

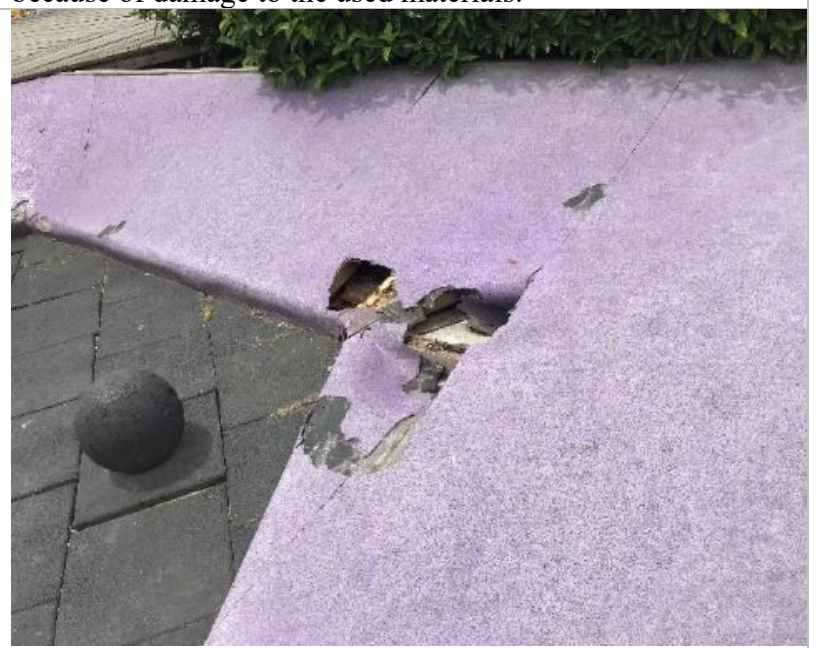

The material in the entertainment corner has deteriorated and is left unmaintained. 


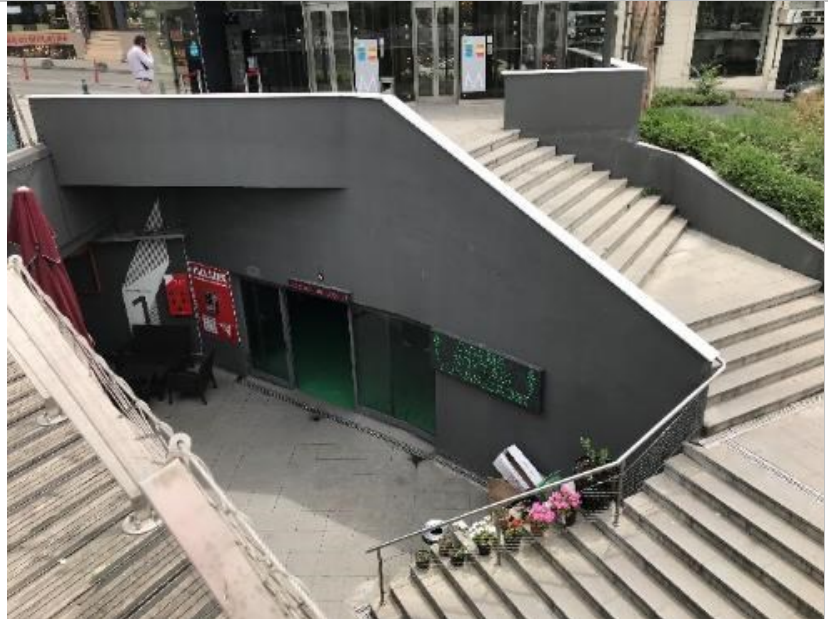

Distribution of the stairs within Şışhane Park was acceptable.

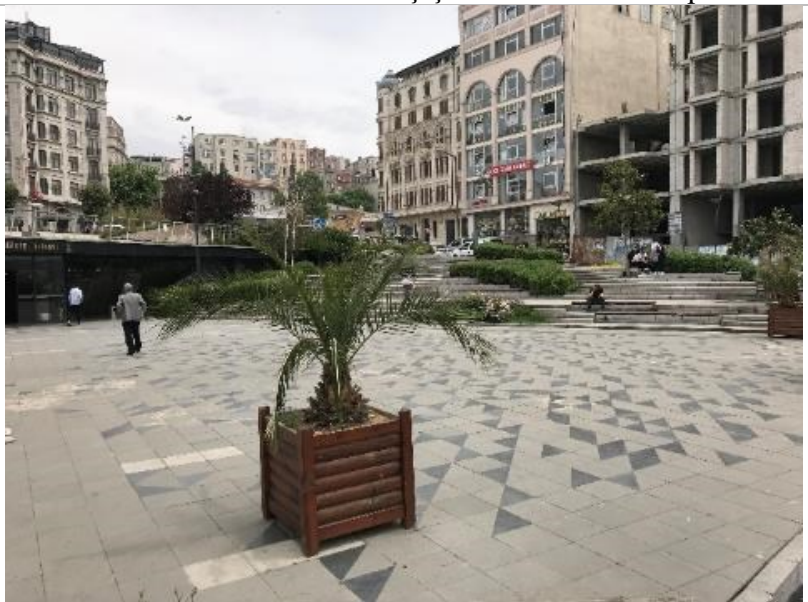

The shape of the planting ponds is suitable for the park elements.

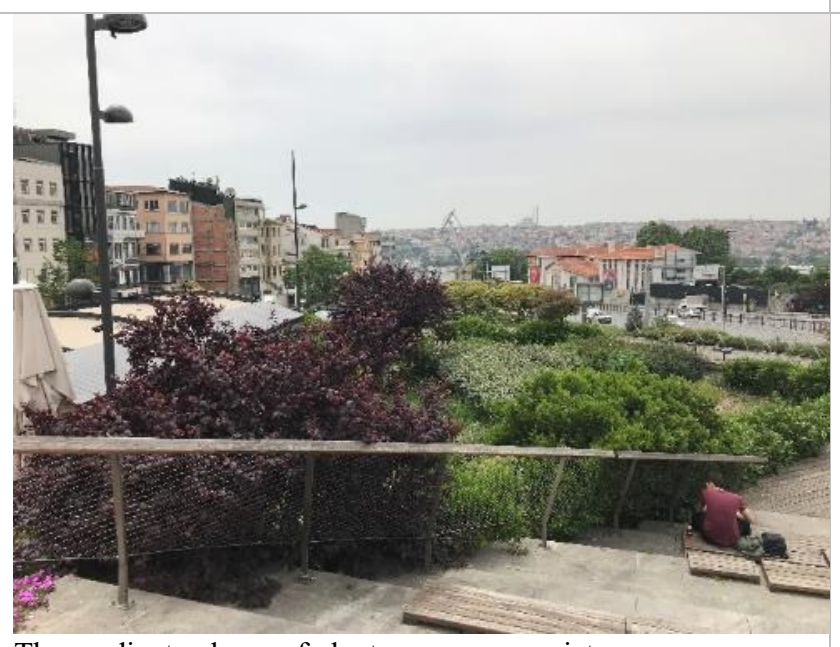

The gradient colours of plants were appropriate.

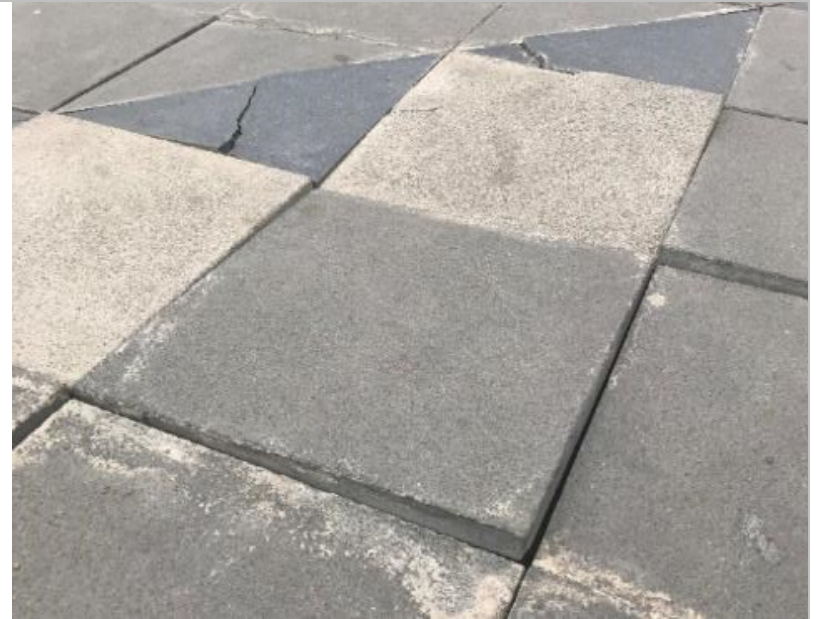

Ground floor tiles are short-lived and of poor quality.

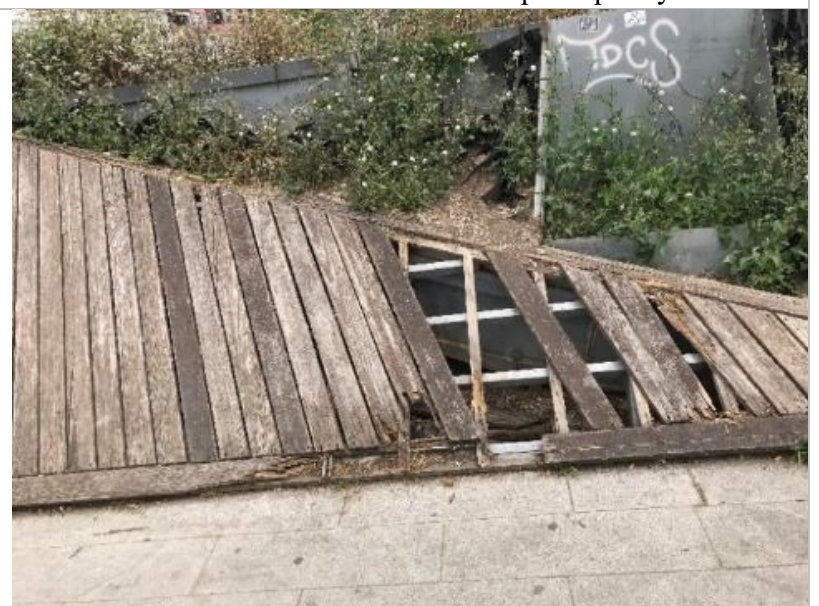

The quality of the used wood materials in the park is very poor and needs maintenance.

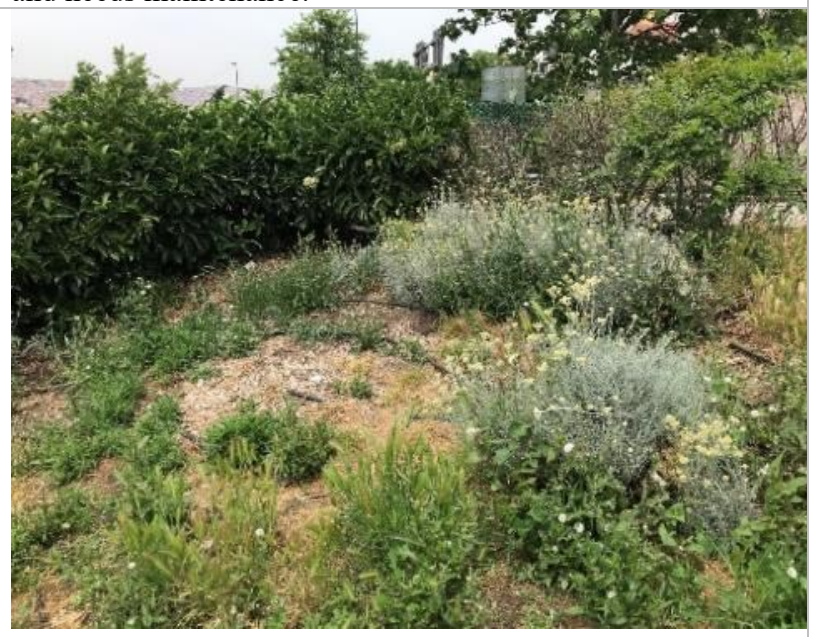

The plants in Ş1şhane park need attention and care. More thoughtful landscaping with a diversity of types.
The assessment of the Aesthetic elements of Şıshane Park (2014- 2019) has revealed that most of the aesthetic characteristics of this park have deteriorated. The harmony of the elements of the design existed previously, but the addition of the exterior cafe has not been studied. The harmony between the elements of the park has been weakened. The characteristics of the scale, texture, colour, materials and visual perception have become worse over time. The psychological impact now is weaker due to neglect of the park's maintenance. 
Table 6. Analysis of "Şı̧̧hane Park" according to derived aesthetic standards; (Improved by author); figures source (Before: URL8, after: by authors)

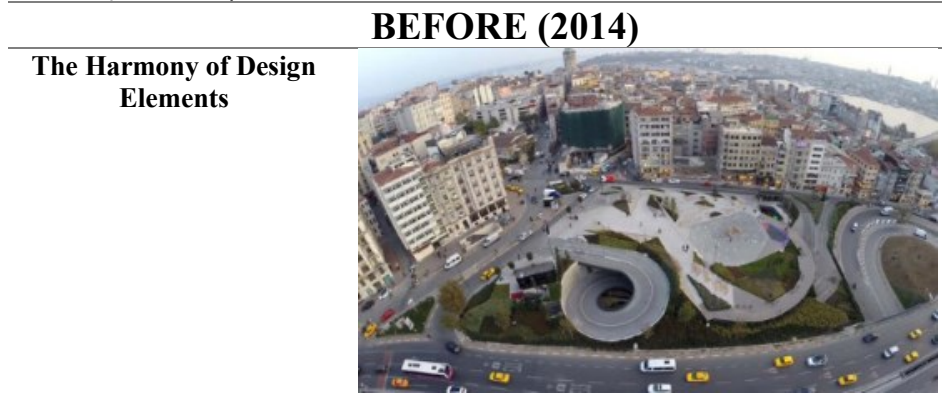

AFTER (2019)
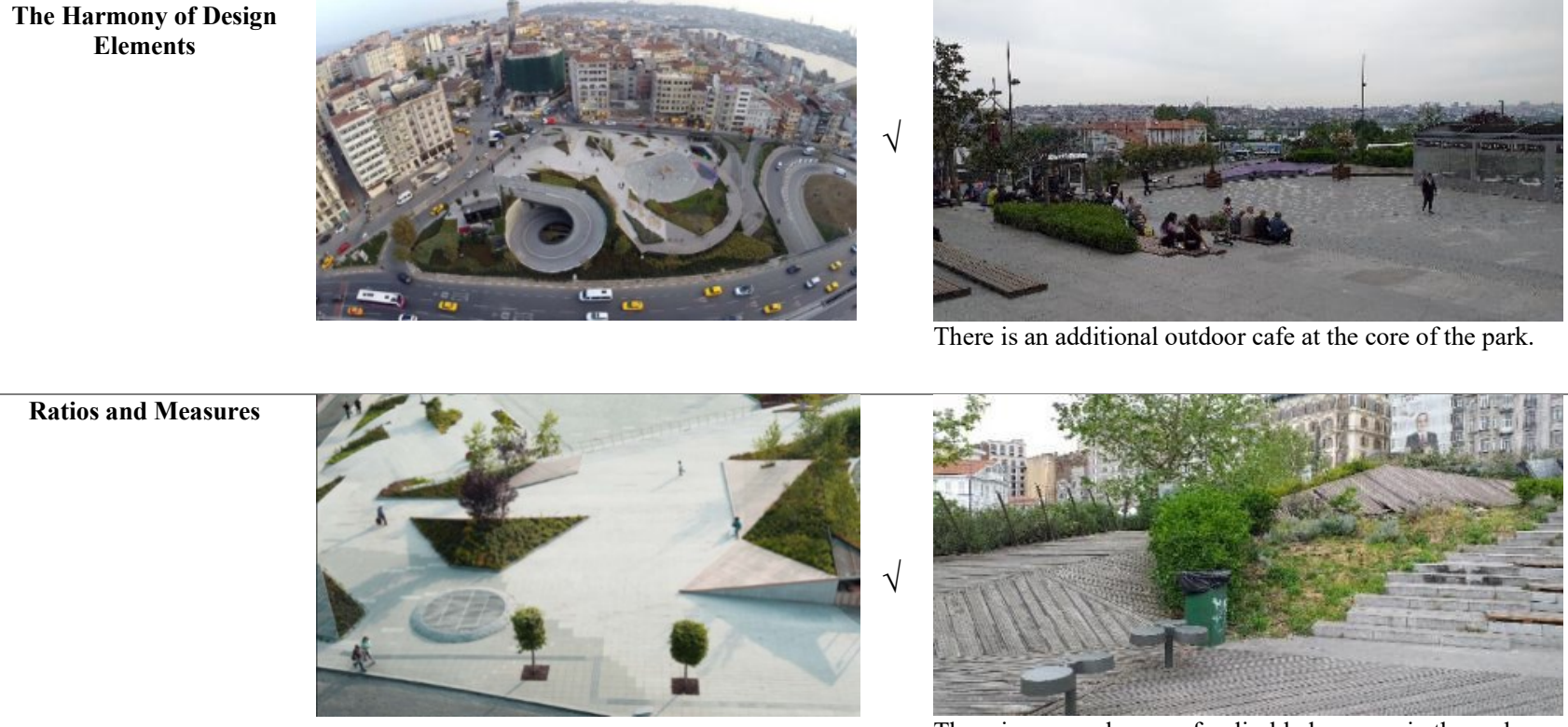

There is an additional outdoor cafe at the core of the park.
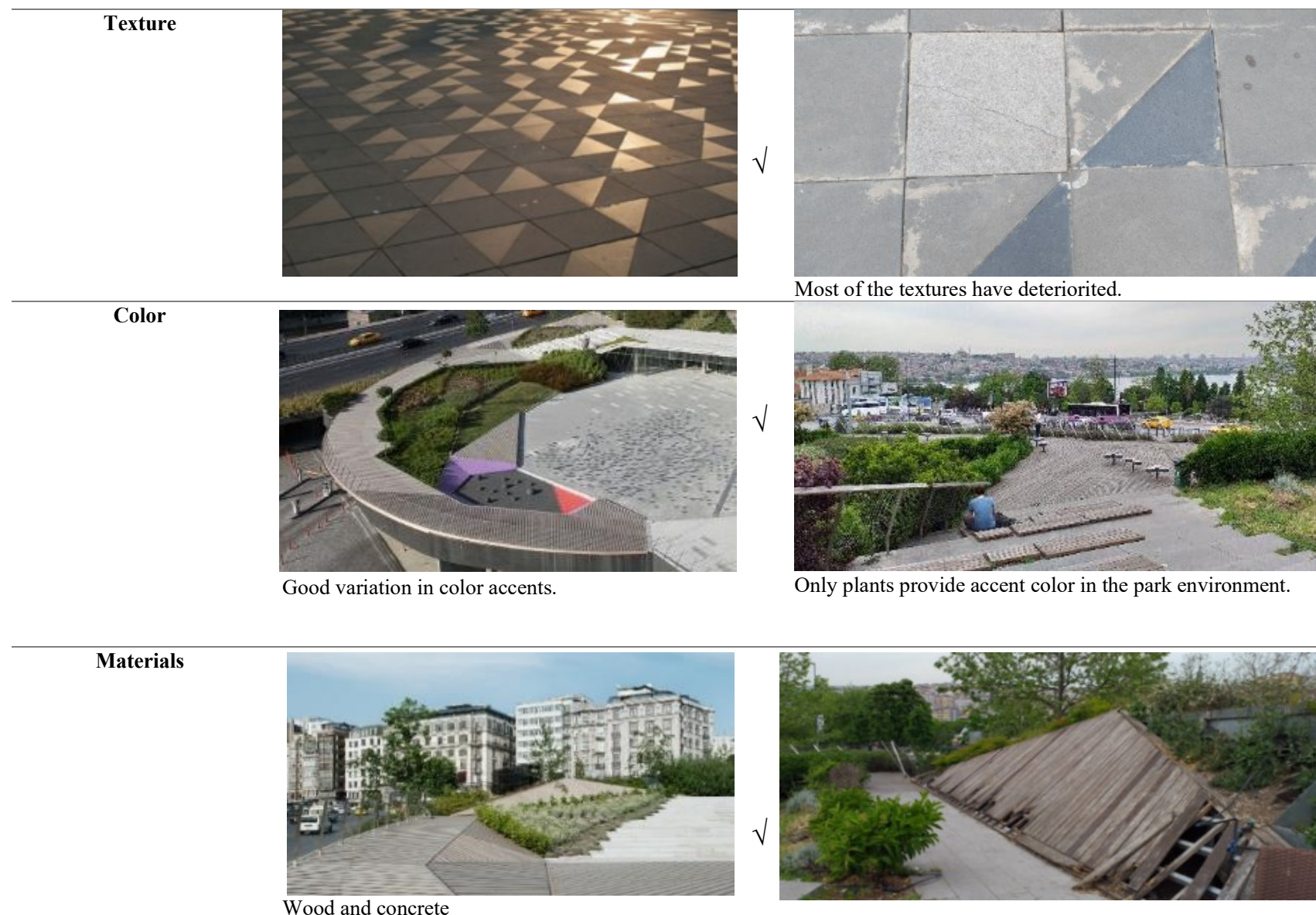

Most of the textures have deteriorited.

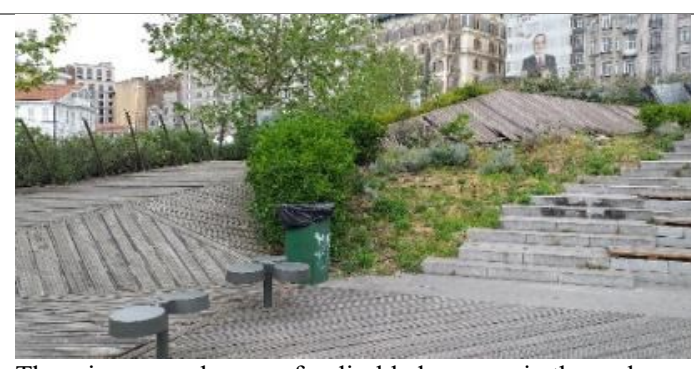

There is no equal access for disabled persons in the park.

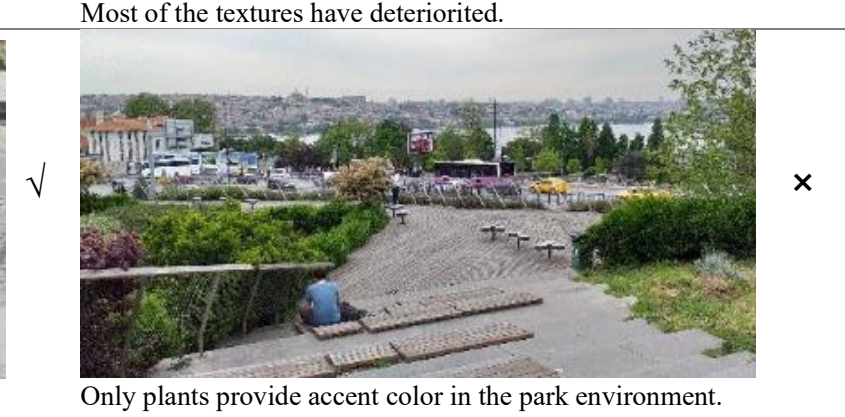

Only plants provide accent color in the park environment.

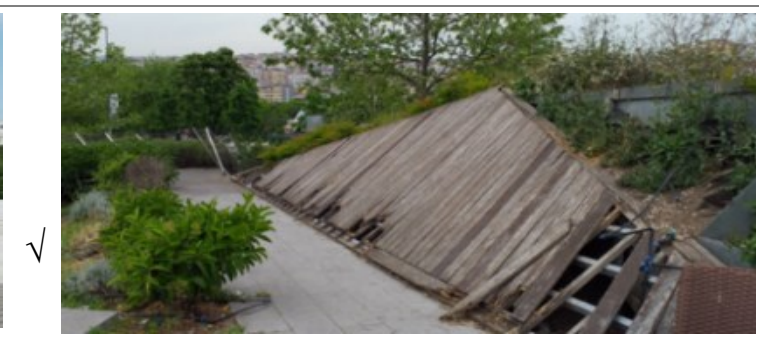

Most of the textures have deteriorated. 

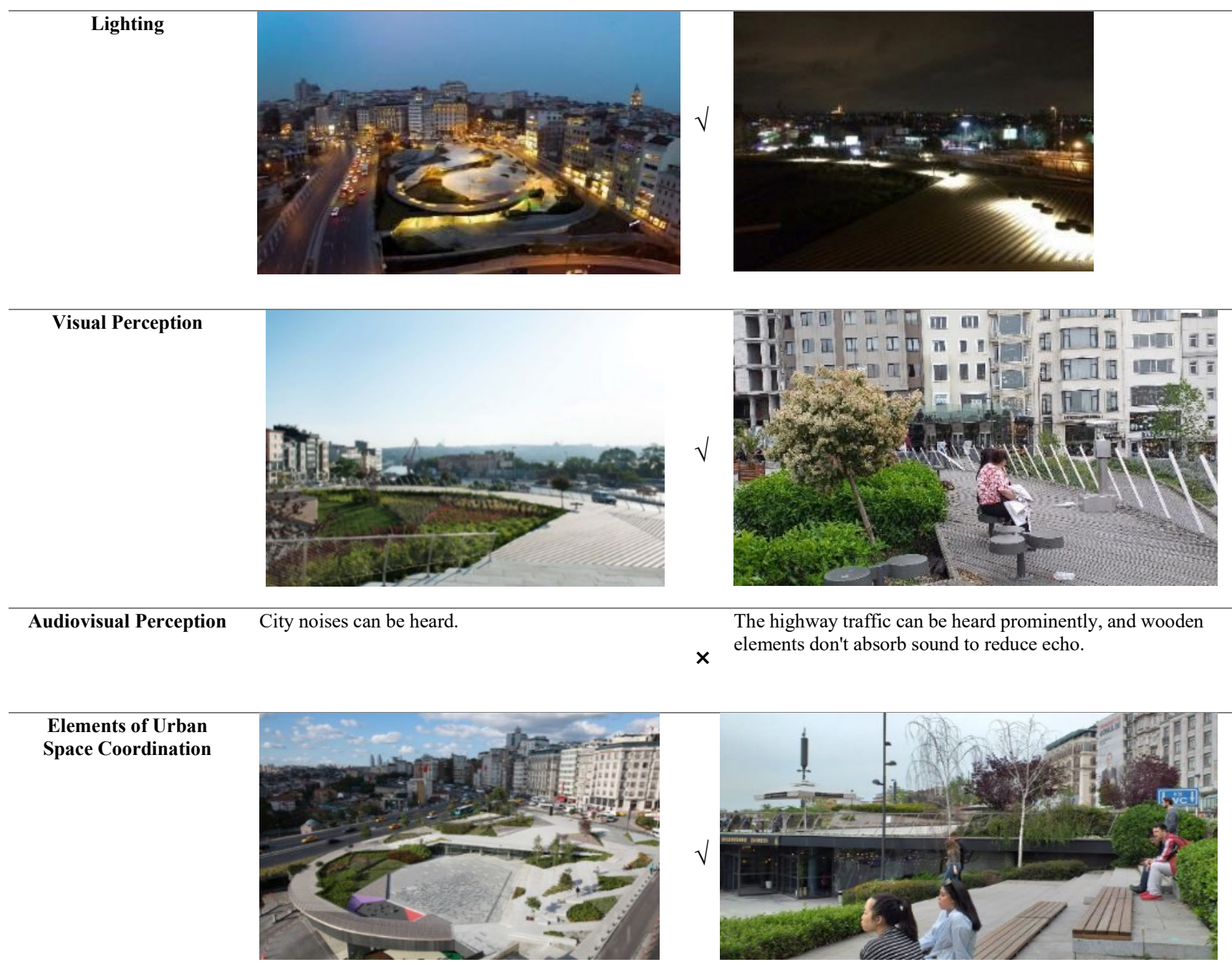

The highway traffic can be heard prominently, and wooden $\times$

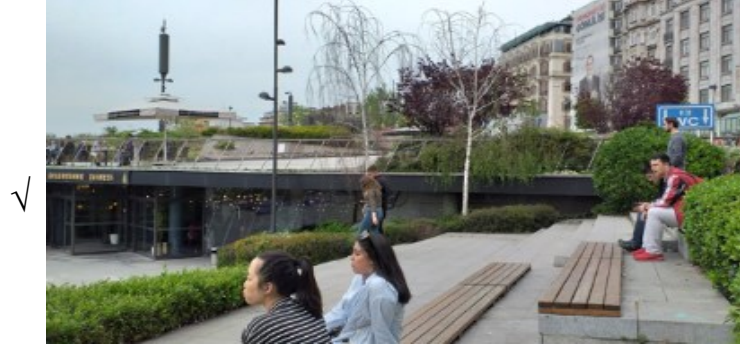

The option to add the outdoor cafe was not successful.

Şıshane Park offers a large public open space for cultural events as well as smaller intimate spaces for resting, enjoying the shade of trees, playing, and spending time in groups. It also features well designed and visually engaging underground parking for up to 1000 vehicles which partly connects with some of nature in the park above. It is a place to experience the urban context of Istanbul while having a strong connection with the surrounding natural environment.

It was observed that the functional characteristics of Şıshane Park were slightly affected by the deterioration of the aesthetic properties of its elements. For the characteristics of diversity, traffic movement, communication, entertainment, comfort, and the support of positive behaviour, these characteristics have not weakened over time. However, the method of organizing the public space is worse because of the external cafe on its main road. There is no possibility of doing sports activities there. 
Table 7. Analysis of "Şışhane Park" according to derived functional elements; (Improved by author) (Figures source: Before- URL8, after- by authors).
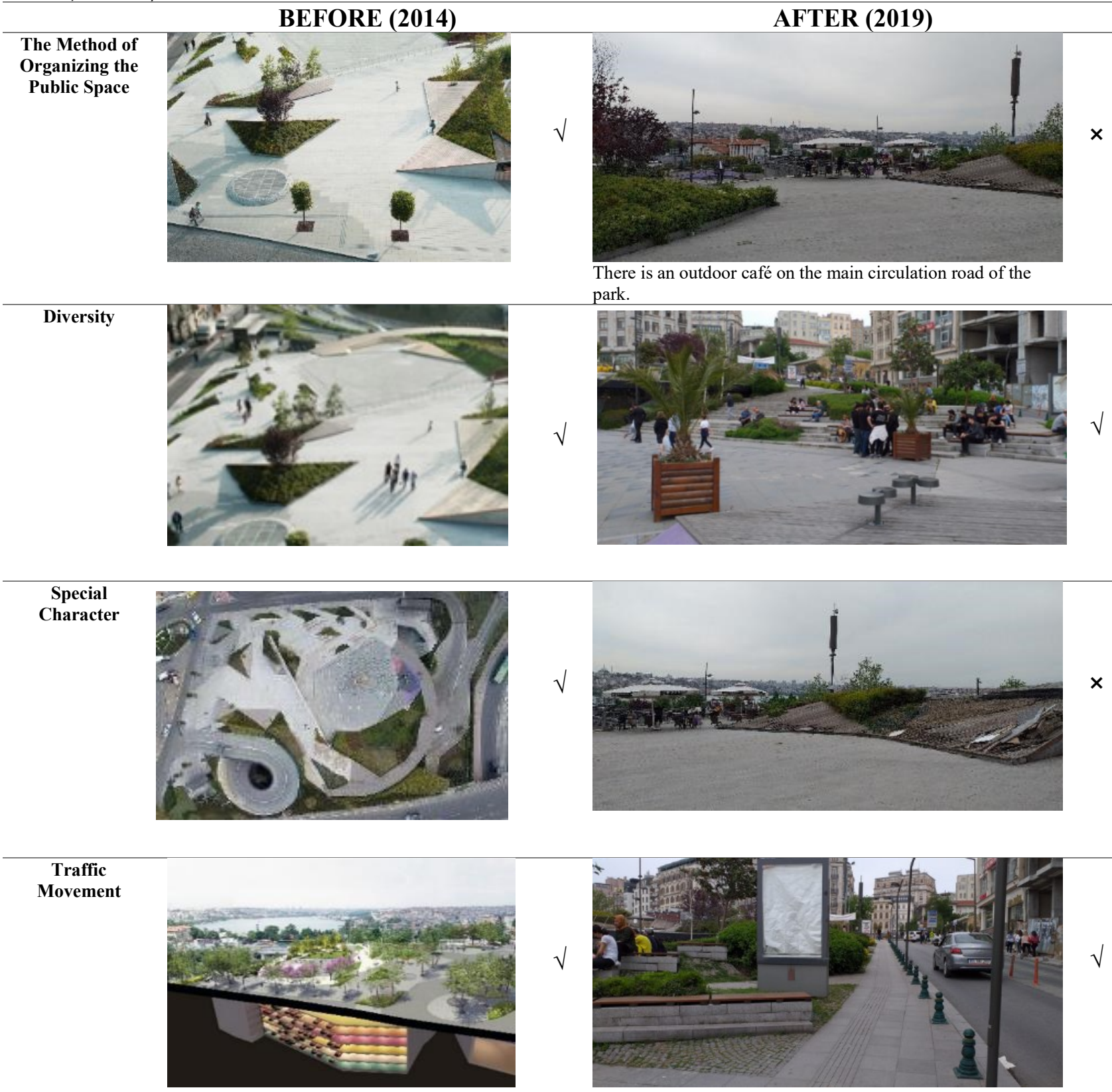

Sports

Activities

$x$
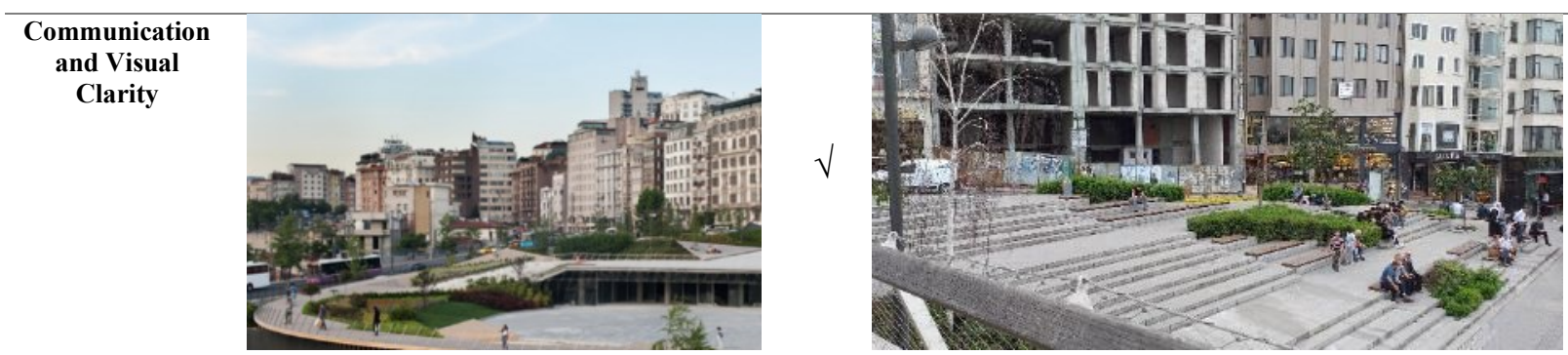

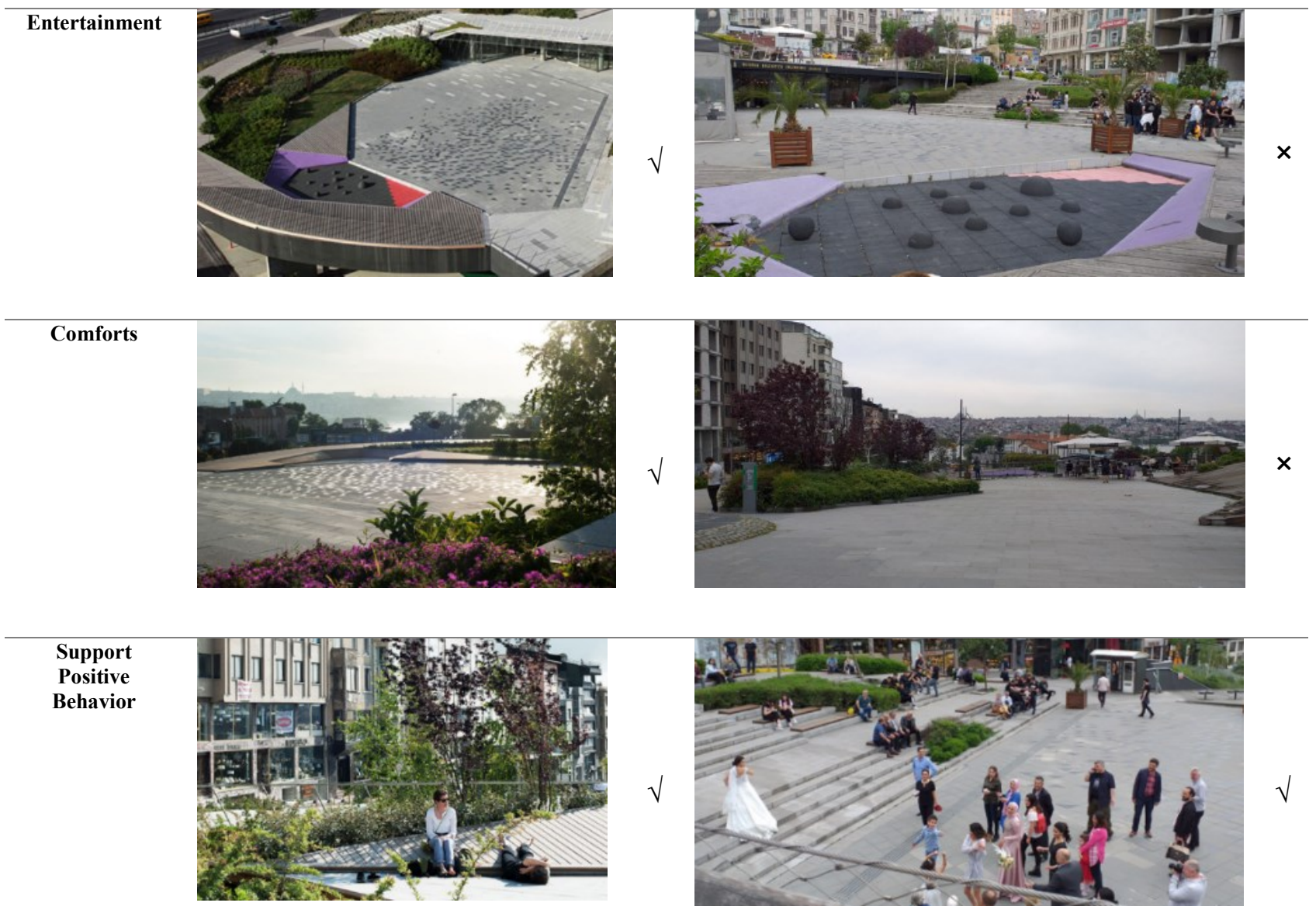

The intention behind Şışhane Park is to revitalize the level of interaction of residents and visitors with the natural characteristics of this unique urban environment.

Energy + Natural Light/Ventilation:

The motion sensor system for lighting and LED lighting makes it possible to supply the park with sustainable power. The upper level of parking is open to the air and natural light while the five lower levels are ventilated by cross ventilation and an automatic fan system. Also, the drawings of a walking man encourage people to take the stairs for more movement.

Water Recapture, Stormwater + Heat Island Effect:

The water restoration system for the large green roof panel does not require maintenance. This reduces the surface of the landscape, wooden floors and light granite options by $30 \%$ of the damage to the heat island effect. These features also reduce the project's impact on stormwater infrastructure in the historic region.

It was observed that most of the environmental characteristics of Şıshane Park were not achieved except to provide a sustainable solution, natural lighting, and good ventilation. This project aims to form the Şişhane Park gate to
Galata and other Beyoğlu neighbourhoods as well as to promote social life in Kasımpaşa. The upper terrace creates a view surface through Haliç which enhances the dense and noisy area of the Tarlabaşı road consisting of six lanes. The center creates a protected outer space, and the third allows the flow of natural light and ventilation to the entrance level near the parking area. Both upper and lower seats are formed in the face of moderation and summer solstice while plants and terraces ease noise pollution in the city center. 
Table 8. Analysis of "Şışhane Park" according to derived environmental elements; (Improved by author); figures source (Before: URL8, after: by authors).

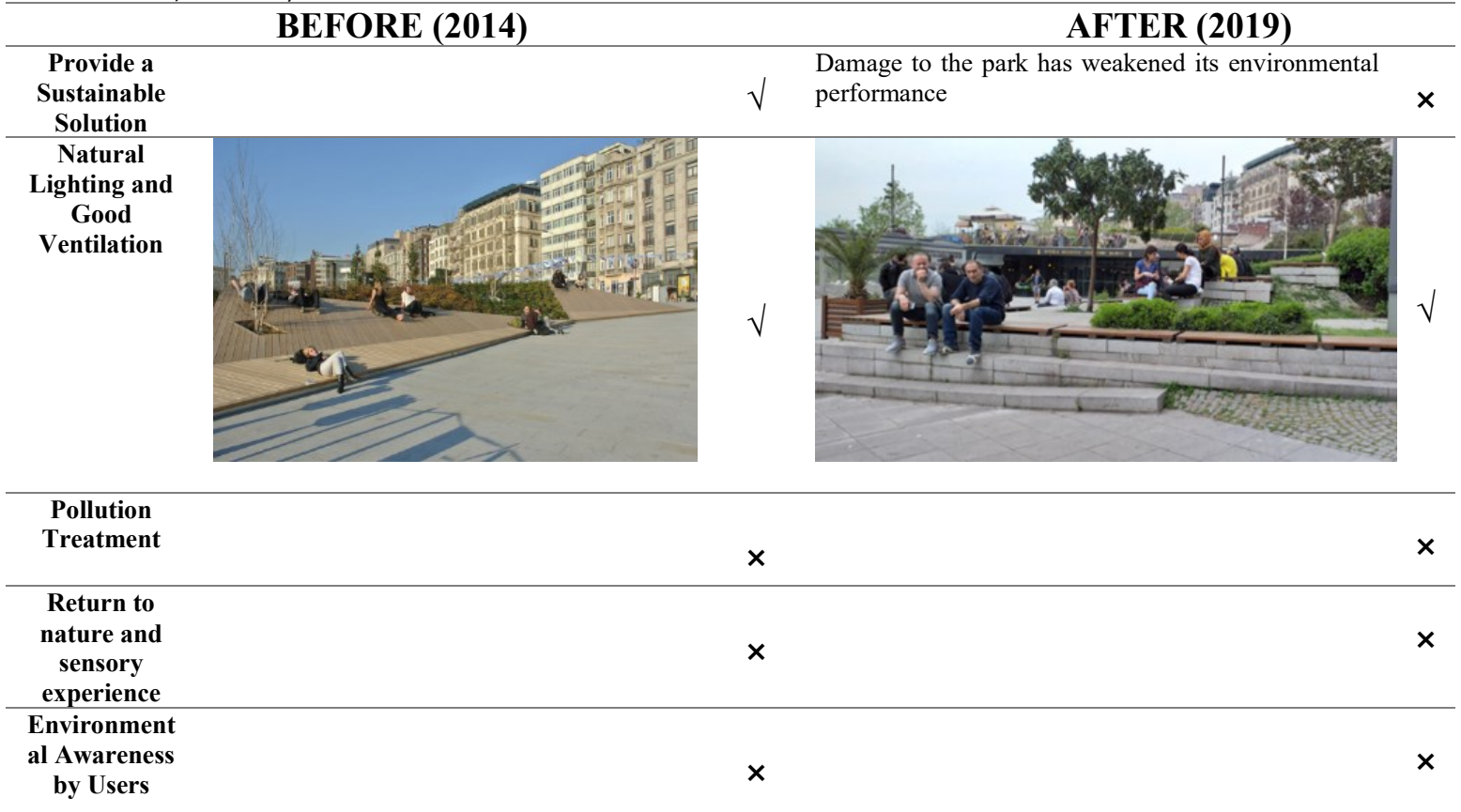

Table 9. Analysis of "Şışhane Park" according to derived aesthetic, functional and environmental standards; (Improved by authors).

\begin{tabular}{|c|c|c|c|c|c|c|c|c|}
\hline \multicolumn{3}{|c|}{ AESTHETIC ELEMENTS } & \multicolumn{3}{|c|}{ FUNCTIONAL ELEMENTS } & \multicolumn{3}{|c|}{$\begin{array}{c}\text { ENVIRONMENTAL } \\
\text { ELEMENTS }\end{array}$} \\
\hline & Before & After & & Before & After & & Before & After \\
\hline $\begin{array}{l}\text { The Harmony of } \\
\text { Design Elements }\end{array}$ & $\sqrt{ }$ & $x$ & $\begin{array}{l}\text { The Method of } \\
\text { Organizing the } \\
\text { Public Space }\end{array}$ & $\sqrt{ }$ & $x$ & $\begin{array}{l}\text { Provide A } \\
\text { Sustainable } \\
\text { Solution }\end{array}$ & $\sqrt{ }$ & $x$ \\
\hline $\begin{array}{l}\text { Ratios and } \\
\text { Measures }\end{array}$ & $\sqrt{ }$ & $\sqrt{ }$ & Diversity & $\sqrt{ }$ & $\sqrt{ }$ & $\begin{array}{l}\text { Natural Lighting } \\
\text { and Good } \\
\text { Ventilation }\end{array}$ & $\sqrt{ }$ & $\sqrt{ }$ \\
\hline Texture & $\sqrt{ }$ & $x$ & Special Character & $\sqrt{ }$ & $x$ & $\begin{array}{l}\text { Pollution } \\
\text { Treatment }\end{array}$ & $x$ & $x$ \\
\hline Color & $\sqrt{ }$ & $x$ & Traffic Movement & $\sqrt{ }$ & $\sqrt{ }$ & $\begin{array}{l}\text { Return to nature } \\
\text { and sensory } \\
\text { experience }\end{array}$ & $x$ & $x$ \\
\hline Materials & $\sqrt{ }$ & $x$ & Sports Activities & $x$ & $x$ & \multirow{6}{*}{$\begin{array}{l}\text { Environmental } \\
\text { Awareness by } \\
\text { Users }\end{array}$} & \multirow[t]{6}{*}{$x$} & \multirow[t]{6}{*}{$x$} \\
\hline Lighting & $\sqrt{ }$ & $\sqrt{ }$ & $\begin{array}{l}\text { Communication } \\
\text { and Visual Clarity }\end{array}$ & $\sqrt{ }$ & $\sqrt{ }$ & & & \\
\hline Visual Perception & $\sqrt{ }$ & $x$ & Entertainment & $\sqrt{ }$ & $x$ & & & \\
\hline $\begin{array}{l}\text { Audiovisual } \\
\text { Perception }\end{array}$ & $x$ & $x$ & Comforts & $\sqrt{ }$ & $x$ & & & \\
\hline $\begin{array}{l}\text { Elements of } \\
\text { Urban Space } \\
\text { Coordination } \\
\end{array}$ & $\sqrt{ }$ & $x$ & \multirow[t]{2}{*}{$\begin{array}{l}\text { Support Positive } \\
\text { Behavior }\end{array}$} & \multirow[t]{2}{*}{$\sqrt{ }$} & \multirow[t]{2}{*}{$\sqrt{ }$} & & & \\
\hline $\begin{array}{l}\text { Psychological } \\
\text { Impact }\end{array}$ & $\sqrt{ }$ & $x$ & & & & & & \\
\hline
\end{tabular}

\section{Results and Discussion}

This research highlights the main characteristics of successful urban open space in terms of aesthetics, function, and the environment, the importance of their integration, and their close association with each other. This was achieved through the study of established views by prominent researchers on this subject to identify essential elements to efficient and successful urban open spaces. For further verification, the previously inferred Standards (aesthetic, functional, and environmental) have been applied to successful global examples that have met these criteria and received numerous 
architectural awards, as well as people- and user- satisfaction.

These examples were presented and analyzed to clarify the main reasons for their construction and the successful methods of dealing with the imbalance in the place. Lastly, this research provided an analysis of the essential design elements for urban open spaces in "Şıshane Park" to display the strengths and weaknesses, to raise the quality of public spaces in the world generally, and in Istanbul in particular.

Overall the condition of the Şıshane Park was previously better and has shown severe deterioration over time (5 years) that has affected the park's efficiency and use by the population.

- In aesthetic terms, many of its characteristics have been lost, and its condition deteriorated badly; such as harmony, texture, colour, materials, visual perception, elements of urban space coordination and psychological effect.

- The deterioration of aesthetic properties in "Şıshane Park" weaken the functional and environmental characteristics.

- There is a clear shortfall of environmental characteristics.

- According to the analysis part of the study, it can be said that aesthetic aspects have greatly affected the use and success of the space more than other factors - the neglected value of the park make it useless and unusable, and turned it into a mere multi-story garage.

- Environmental aspects were the hardest hit among other aspects, followed by aesthetics aspects, and functional aspects were the least affected.

The purpose of this research is to clarify the importance of the interrelation of aesthetic, functional, and environmental factors among them, and their impact on urban open space. Taking into account these factors in the process of urban design is important to the product's efficiency and success. It was also noted that most of the previous studies dealt with one of these factors affecting urban open space. Therefore, it is important that characteristics must be met across all three aesthetic, functional, and environment for the success of urban open space. Additionally, the criteria across these considerations should be integrated, both in research and in urban planning and design. Examining the case study of Şişhane Park, which is considered one of the most important modern parks located in a historical area, helps to understand the inter-relationships between these elements, and how they affect one another in failure. Although "Şişhane Park" has won many awards for its unique design, the current state it has become very poor. It has lost many of its advantages over time. It becomes clear that the application of urban open space standards to the design and planning of any urban open space will result in a truly aesthetically pleasing, functionally successful, and environmentally respectful space that preserves the environment and is used by people.

\section{Acknowledgement}

This research did not receive any specific grant from funding agencies in the public, commercial, or not-for-profit sectors.

\section{Conflict of interests}

The authors declare no conflict of interest.

\section{References}

Abdullah, I. H. (2009). Aesthetic theory in the art of design. Modern Discussion, no.2677, (reference in Arabic). Available: http://www.ahewar.org/debat/show.art.asp?aid=1 75060

Al-Dweikat, F. (2009). Urban Public Spaces in the City of Nablus and their Development Physically and Visually "An analytical Study of the Eastern Complex Area". Nablus, Palestine. https://repository.najah.edu/handle/20.500.11888 17534

Al Farran, H. (2010). Determinants of Visual Design for Urban Public Spaces in the Arabic City. Journal of Urbanization and Urban Technologies: University of Messila, Algeria. https://www.researchgate.net/publication/259266 740 Determinants_of_Visual_Design_for_Urban _Public_Spaces_in_the_Arabic_City

Alyari, M. (2018). Role of environmental psychology in strategic development of urban public spaces based on aesthetic needs of citizens. Journal of Urban Design and Mental Health. https://www.urbandesignmentalhealth.com/journ al-5---urban-visual-perception.html

Barton, H \& Tsourou, C. (2000). Healthy urban planning. Spon press, London. https://doi.org/10.4324/9780203857755

Blackburn, S. (1994). The Oxford Dictionary of Philosophy. Oxford: Oxford University Press.

Borton \& M, (2006). Inclusive Urban Design: Streets for Life. Architectural press: Linacre house, Jordan hill, Oxford OX2 8DP, UK. 
Carmona, M \& others. (2010). Public Spaces - Urban Spaces: The Dimensions of Urban Design. Second Edition, Architectural Press:Great Britain.

Corbum, J. (2009). Toward the Healthy City: People, Places, and the Politics of Urban Planning. The MIT press. London, England.

Elmashad, A. (2011). Urban design standards and its implications for security in the new urban areas, $\mathrm{PhD}$ thesis. Helwan University, Egypt.

Gauzin-Müller, Dominique and Favet, Nicolas. (2002). Sustainable Architecture and Urbanism: Concepts, Technologies, Examples. Basel. Berlin. Boston.

Hahn, E. (1987). Oekologische Stadtplanung (paper on ecological urban planning). H\&H, Frankfurt Am: Germany.

Jacobs, A and Appleyard, D. (1987). Toward an Urban Design Manifesto. Planner's Notebook. https://pdfs.semanticscholar.org/293a/15cd8ad1e 63d3676e577dca120872a80e771.pdf

Jacobs, Jane (1961). The Death and Life of Great American Cities. New York: Random House. https://www.buurtwijs.nl/sites/default/files/buurt wijs/bestanden/jane_jacobs_the_death_and_life_ of great_american.pdf

UMBAU-VERLAG, Solingen, Germany. https://books.google.com.tr/books?id=brVKqC90 TfIC\&printsec $=$ frontcover\&source $=$ gbs ge sum mary_r\&cad $=0 \# \mathrm{v}=$ onepage $\& \mathrm{q} \& \mathrm{f}=$ false

Krier, R. (1991). Urban Space, Academy Education, London, $\mathrm{p}$ https://tr.scribd.com/document/150062548/RobKrier-Urban-Space

Lynch, K. (1960). The Image of the City, Massachusetts Institute of Technology. Cambridge, Massachusetts, and London, England.

Lynch, K. and Hack, G. (1994). Site Planning. 3rd Ed. The MIT Press, London.

Nasar, J. L. (1998). The evaluative image of the city. Thousand Oaks, CA: Sage Publications.

Nia, H. A. and Atun, Resmiye Alpar. (2015). Aesthetic design thinking model for urban environments: A survey based on a review of the literature. Department of Architecture, Eastern Mediterranean University, Salamis, Mersin, Gazimagusa $\quad 10, \quad$ Turkey. https://www.researchgate.net/publication/288040 958_Aesthetic_design_thinking_model_for_urba n_environments_A_survey_based_on_a_review_ of the literature
Punter \& Carmona, (1997). The Design Dimension of Planning: Theory, content and best practice for. E and FN spon, London, UK.

Shaftoe, Henry. (2008). Convivial Urban Spaces. UK and USA.

Stevens, Quentin. (2006). The shape of urban experience: a reevaluation of Lynch's five elements. Environment and Planning B: Planning and Design, Volume33, Pages 803-823. https://pdfs.semanticscholar.org/24bd/2ff2c02c6f b8d51db6edb406f5b094c9bf93.pdf

Tay, E, Canbay Türkyilmaz, Ç. (2018). Açik alan ergonomisine dair bir inceleme, şişhane parki ve katli otoparki [An examination on outdoor ergonomy, şişhane park and şişhane car park], Journal of Engineering Sciences and Design, $6(0)$, 205-219. DOI: $10.21923 /$ jesd.360652

Tibbalds, Francis. (1992). Making People-friendly Towns. Longman Group, UK, Ltd.

Turner, A. (1980). Cities of the Poor: settlement planning in developing countries, Croon Helm, London. https://doi.org/10.3828/twpr.3.1.e0650507m8972 807

Williams, Katie \& others. (2000). Achieving Sustainable Urban Form. E \& FN Spon, London and New York.

URL-1. https://medium.com/@thejas009/the-importanceof-public-spaces-5bb49ba6c000

URL-2. https://www.wmagazine.com/story/anish-kapoornra-cloud-gate-sculpture

URL3.https:/www.archdaily.com/908050/jaworznickieplanty-water-playground-rs-plus-robert-skitek

URL-4. https://www.archdaily.com/620408/thesoundwave-penda

URL-5. https://www.archdaily.com/286223/superkilentopotek-1-big-architects-superflex

URL-6. https://www.archdaily.com/912462/usaquenurban-wetland-cesb-obraestudio

URL-7.https://www.archdaily.com/97830/victor-civitaplaza-open-museum-of-sustainability-leviskyarquitectos-associados

URL-8.

http://www.landezine.com/index.php/2014/11/sishanepark-by-sanalarc/

Check for

Updates

How to Cite this Article:

Hamameh, S and Caymaz, G. F. Y. (2020). Evaluation of Aesthetic, Functional, and Environmental Effects on the Design of Urban Open Spaces: A Case Study of İstanbul Şişhane Park, Turkey. Journal of Contemporary Urban Affairs, 4(2), 67-86. https://doi.org/10.25034/ijcua.2020.v4n2-7 
www.ijcua.com

This page is intentionally left blank. 